$\begin{array}{cc}\text { Türk Coğrafya Dergisi } \\ \text { Basılı ISSN 1302-5856 } & \text { Turkish Geographical Review } \\ \text { www.tcd.org.tr } & \text { Elektronik ISSN 1308-9773 }\end{array}$

\title{
Modernizmin üretim mekânından postmodernizmin tüketim mekânına: Ak-İş iplik fabrikası- Palladium Antakya AVM örneği
}

\section{From the production space of modernism to the consumption space of postmodernism: The example of Ak-Is yarn factory- Palladium Antakya shopping center}

\author{
Yücel Dinç*a (i) Çetin Furkan Usun b \\ ${ }^{a}$ Hatay Mustafa Kemal Üniversitesi, Fen Edebiyat Fakültesi, Coğrafya Bölümü, Hatay, Türkiye. \\ ${ }^{b}$ Hatay Mustafa Kemal Üniversitesi, Fen Edebiyat Fakültesi, Coğrafya Bölümü, Hatay, Türkiye.
}

ORCID: Y.D. 0000-0002-0492-4724; Ç.F.U. 0000-0002-5205-8752

\section{BILGI / INFO}

Geliş/Received: 15.06.2021

Kabul/Accepted: 13.10.2021

\section{Anahtar Kelimeler:}

Mekân

Modernizm

Postmodernizm

Üretim

Tüketim

\section{Keywords:}

Space

Modernism

Postmodernism

Production

Consumption

*Sorumlu yazar/Corresponding author:

(Y. Dinç) dyucel.13@hotmail.com

DOI: $10.17211 /$ tcd.952714

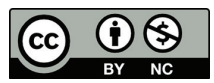

\section{Atif/Citation:}

Dinç, Y., \& Usun, Ç. F. (2021). Modernizmin üretim mekânından postmodernizmin tüketim mekânına: Ak-iş̧ iplik fabrikası- Palladium Antakya AVM örneği. Türk Coğrafya Dergisi, (78), 7-22. https://doi.org/10.17211/tcd.952714

\section{ÖZ / ABSTRACT}

Türkiye'de 1950'li yıllardan 1980'li yıllara kadar emek gücüne dayalı kentleşme süreçleri meydana gelmiş ve bu süreç 1980 'lerden itibaren kentsel mekânda gerçekleşen neoliberal uygulamalara bağlı olarak yerini sermaye birikimine bağlı kentleşme süreçlerine bırakmıştır. Kentsel mekânlarda bu şekilde meydana gelen değişim ve dönüşümlerin en somut örneklerinden biri, kent merkezlerinde yer alan endüstriyel tesislerin değişen ekonomik şartlara bağlı olarak yerini alışveriş merkezlerine bırakmaları olmuştur. Bu çalışmanın motivasyonunu; "fabrikaya yönelik aidiyet duygularına sahip üreten bir toplumdan, alışveriş merkezinin misafirleri durumundaki tüketen bir topluma geçiş sürecinde kentsel mekân nasıl şekillenmektedir?" sorusu oluşturmaktadır. Hizmete girdiği 1950'li yıllarda Hatay’ın en büyük üretim merkezi olan Ak-iş iplik fabrikası zamanla işlevini yitirerek yıkılmış ve onun yerine bir alışveriş merkezi inşa edilmiştir. Emek gücünden sermaye birikimine doğru gerçekleşen bu dönüşümün Antakya kentsel mekanını nasıl şekillendiğini ampirik analizlerle ortaya koymak bu çalışmanın temel amacıdır. Çalışmada hem nicel hem de nitel verilerin birlikte değerlendirilmesi anlayışını benimseyen karma yöntem kullanılmıştır. Nitel veriler, Ak-İş iplik fabrikasından emekli olmuş 5 kişiyle gerçekleştirilen derinlemesine görüşmelerden elde edilmiştir. Nicel verilerin elde edilebilmesi için ise Antakya'da ikamet eden 265 katılımcıya anket uygulanmıştır. Çalışmanın nitel bulguları; emek gücü, kentsel bellek ve mekân kullanımı olmak üzere üç temaya dayanmaktadır. Nitel bulgular, bir üretim mekânı olarak fabrikanın yeni mekânların üretilmesinde önemli roller üstlendiğini göstermiştir. Nicel verilerden ve alan araştırmalarından elde edilen bilgiler ise; kentsel mekânın tüketim ve sermaye odaklı olarak önemli değişim ve dönüşümler geçirdiğini ortaya koymuştur.

From the 1950s to the 1980s, urbanization processes based on labor power occurred in Turkey, and this process has been replaced by urbanization processes based on capital accumulation due to the neoliberal practices that have taken place in urban space since the 1980s. One of the most concrete examples of the changes and transformations that took place in urban spaces in this way is the industrial facilities located in city centers being replaced by shopping centers because of the changing economic conditions. The research question that motivates this study is: "How is the urban space shaped in the transition from a producing society with a sense of belonging to the factory to a consuming society as the guests of the shopping mall?". Ak-iş yarn factory, which was the largest production center of Hatay in the 1950s when it was put into service, lost its function over time and was demolished and a shopping center was built in its place. The aim of this study is to reveal how this transformation from labor power to capital accumulation shaped the urban space of Antakya with empirical analysis. In the study, the mixed method, which assesses both quantitative and qualitative data, was employed. The qualitative data were obtained from in-depth interviews with five retired employees from the Ak-iş Yarn Factory. In order to collect the quantitative data, a questionnaire was administered to 265 participants residing in Antakya. The qualitative findings of the study were based on three themes, namely labor power, urban memory, and space use. Qualitative findings revealed that the factory, as a production space, played an important role in the production of new spaces. Information obtained from quantitative data and field observations, on the other hand, revealed that urban space underwent significant changes and transformations with a focus on consumption and capital. 
Extended Abstract Introduction

The transition from modernism to postmodernism refers to a process that includes the transformation from the production society/space to the consumption society/space. While factory, transportation, and neglected environmental conditions were the three basic elements of the city in modernism, the most basic elements of postmodernism in cities have been consumption and entertainment venues such as shopping malls and hotels. Thus, capital assigned new functions to the space. In the 1950s, with both the direct effects of the nation-state understanding and the increasing capital, the built domain of production started to be built and urban settlements (traditional attraction centers such as Istanbul, Ankara, İzmir, Adana) developed rapidly as labor-based production areas. By the 1980s, the capital was transferred from industrial production to areas such as real estate, finance, and tourism, which are not directly productive, thus, capital had decisive effects in the production, restructuring, and transformation processes of urban spaces. In this way, shopping malls, one of the most important consumption places of postmodernism, began to replace factories, which are production spaces. There are many examples of this functional transformation, especially in metropolitan cities of our country.

One of the places where the processes of transforming the factories, which were the production places of a period, into consumption places/shopping centers after demolition or restoration, is the city of Hatay. The purpose of this study is to reveal the transformation processes of Ak-iss Yarn Factory, which was put into service in 1954 and provided significant employment to the local people as the largest production center of Hatay when it started production, from a production space to a consumption space and the socio-spatial effects of these processes in the context of modernism-postmodernism. equation.

\section{Data and Method}

In this study, the mixed method, which assesses both quantitative and qualitative data, was employed. The quantitative data were collected by administering a scale developed by the authors to the local people who go to Palladium Shopping Center in Antakya since it reflects today's consumption society. Qualitative data, on the other hand, were collected through oral interviews with five people who retired from Ak-iş Yarn Factory. These five people were asked exploratory questions about why and how the production process took place. Considering that the Covid-19 pandemic affected the attitudes and behaviors of consumers (such as frequency of visits, shopping preferences, amount of spending) while applying the questionnaire, participants were asked to consider the periods before the pandemic to answer certain questions. Since it was not possible to administer face-to-face questionnaires due to the epidemic, the questionnaire was developed and administered electronically. Quantitative data were analyzed using IBM SPSS_26 and MAXQDA 2020 software. Tables and graphs based on the answers provided were formed and interpreted.

\section{Results and Discussion}

The issue of how to organize the urban space has been and continues to be one of the ongoing debates for years. The ur- banization processes based on the labor force that started in the 1950s in Turkey and the capital and consumption-based urbanization processes that emerged as a result of the neoliberal practices that took place in the 1980 s brought along important transformations in urban spaces. The effort to reveal the effects of these changes and transformations on the city of Antakya formed the main motivation behind this study.

The qualitative findings of the study were based on three themes: labor power, urban memory, and space use. The interviews conducted with five retired employees of the Akiş Yarn Factory revealed that the participants experienced labor-based urbanization processes and that the factory has an important place in their memories as a production space. The information obtained from the in-depth interviews showed that the factory, as a production space, had significant effects on the production of new spaces (such as the establishment and development of Akevler Neighborhood, squatting).

The findings obtained from the observations on the field and the quantitative data put that the urban space underwent significant changes and transformations due to consumption and capital. First of all, with the demolition of the ruined factory and the construction of a shopping center in its place, the rundown, unhealthy and unsafe environment disappeared. As a matter of fact, one of the survey questions was "What is the most important problem around the Palladium Shopping Center?" The fact that only $1.5 \%$ of the participants gave 'security' as an answer to the question supports this.

With the opening of the shopping center, one of the most striking changes in the city center was the transition from street retailing to shopping center retailing. Atatürk Boulevard, which was the most important and busiest boulevard of the city before the shopping center was put into service, lost its former importance, some businesses were completely closed, while others moved to the shopping center. Indeed, the participants were asked the question "Where do you usually do your shopping?" The fact that only $1.9 \%$ of the participants gave 'Atatürk Boulevard' as an answer clearly shows that the boulevard has lost its importance.

Unlike many shopping centers, Palladium was founded next to the historical urban fabric of Antakya. Although the fact that the shopping center is in the city center was welcomed by the respondents, it was stated that it did not match with the city of Antakya in terms of its architectural structure and historical texture. In addition, "What are the first three words that come to your mind when you think of the Palladium Shopping Center?" The most frequently repeated words among the answers given to the question were shopping, dining, movies, crowds, and money. Undoubtedly, these words reflect the characteristics of many shopping centers with a postmodern consumption culture, but the participants also emphasized spatial elements such as the Asi River, bridgehead, and bazaar that can bring Palladium Antakya more to the fore.

\section{Giriş}

Modernizm; çağdaşlık, geleneksel yerine yeni olanı kabul etme, kalıplaşmış davranışları yıkma, koşullardaki sürekli değişimler, kat kuralların yok edilmesi gibi birbirinden farklı ifadelerle an- 
latılan bir kavramdır (Berman, 1988; Kaypak, 2013; TDK, 2021). Tarıma dayalı toplumsal bir yapıdan sanayiye dayalı toplumsal bir yapıya geçiş, modernizmin en önemli özelliklerinden biri olarak kabul edilmektedir (Bayhan, 2006). Modernleşme ise, genellikle az gelişmiş ülkelerin sanayileşmiş ülke modeline uyum sağlayabilmeleri anlamına gelmektedir (Kongar, 2003). Özellikle üretimle ilişkili gelişmelere ayak uydurulabilmesi, yüzyıllardır süregelen geleneksel kalıpların yerine sanayileşme süreçlerini ortaya koyabilecek modernizme dayalı değişimlerin benimsenmesi yoluyla mümkün olmaktadır (Er, 2014).

Kent içerisinde sosyal ve gündelik hayatta meydana gelen gelişmeler kentsel yapıların sabit kalmasını engellemekte ve kentsel yapı zamanın koşullarına göre değişime uğrayabilmektedir. Böylece söz konusu yapılar değişim, dönüşüm ve yenilenme süreciyle karşı karşıya kalmaktadır (Çeker \& Belge, 2015). Sanayi devrimiyle birlikte sermayenin ve üretimin merkezleri hâline gelen kent merkezlerinde, endüstri alanlarının işlevlerini yitirmesi ya da desantralizasyon ile kent dışına taşınması ile kullanım dışı alanlara dönüşen büyük boş alan ve yapıların geleceği her geçen gün daha fazla tartş̧ılmaya başlamıştır (Karadağ \& İncedere, 2020). Yaşanan bu gelişmeler kent merkezlerinde yeni planlamaları gerekli hale getirmiş ve bu durum üretim mekânlarına da yansımıştır (Koçan, 2011; Yaprak, 2019). Eski endüstri alanları zaman içerisinde işlevlerini kaybederek sosyo-ekonomik ve çevresel açıdan kent yaşamını olumsuz etkileyecek mekânlara dönüşmektedir. Bu alanlar, literatürde "terk edilmiş endüstri bölgesi (brownfield)" olarak adlandırılmaktadır (Alker vd., 2000; Karadağ \& Incerede, 2017).

1980'li yıllarda yaşamın birçok alanında gerçekleşen neoliberal uygulamalardan mekânın kendisi de etkilenmiş ve kentler sermayenin hizmetine sunulan birer meta haline dönüşmeye başlamışlardır (Turut \& Özgür, 2018). Böylece 1980'lere kadar üretime öncelik veren sermaye artk yörüngesini tüketim ve hizmetler sektörüne kaydırmış, bu dikkate değer değişim ile birlikte kent literatüründe "postmodernizm" kavramından bahsedilmeye başlanmıştır (Dear, 1986; Harvey, 1990; Dear \& Flusty, 1998; Ellin, 1999; Arvidson, 1999; Dear, 2000; Gottdiener, 2005; Harvey, 2010, Harvey, 2015; Soja, 2015).

Modernizmden postmodernizme geçiş, üretim toplumundan/ mekânından tüketim toplumuna/mekânına dönüşümü içeren bir süreci ifade etmektedir (Kando, 1996; Azizağaoğlu \& Altunışık, 2012; Erdoğan, 2013; Hatipler, 2017). Postmodernizm ile birlikte "modernizmin gelişme eşittir üretim ve sanayileşme" anlayışı değişmeye başlamıştır (Kaygalak \& Işık, 2007). Emekli, (2018) bu değişimi günümüz kentlerini tanımlayan temel ögelerin sundukları hizmet, organizasyon, iletişim, haberleşme gibi olanaklar olmasından dolayı kentlerin üretim merkezi olma işlevlerinden ayrılarak, sanayinin/üretimin kenti tanımlayan temel öge olma özelliğini kaybetmesiyle açıklar (Emekli, 2018). Modernizmde fabrika, ulaşım ve bakımsız çevre şartları kentin üç temel unsuru olurken, postmodernizmin kentler üzerindeki en temel ögeleri ise alışveriş merkezi ve otel gibi tüketim ve eğlence mekânları olmuştur. Böylece sermaye mekâna yeni işlevler yüklemiştir (Eraydın, 1992; Gürsel, 2015).

Türkiye'de, fabrikaların yıkılarak veya restore edilerek alışveriş merkezlerine dönüştürülmesi süreçlerine verilebilecek en iyi örnekler İstanbul'da bulunur. ${ }^{1}$ İstanbul'da Profilo, Philips, Eczacıbaşı, Edip İplik, Altınyıldız, Roche, Ford, Hasel ve Evyap birer alışveriş merkezine dönüştürülen fabrikalardan bazılarıdır. Diğer yandan, Ankara'nın en önemli alışveriş merkezlerinden Ankamall, Denizli'nin Sümerbank, Kayseri'nin Meysu Outlet, Çanakkale'nin 17 Burda, Adana'nın Esas 01 Burda ve Malatya'nın Doğa Cadde Mall alışveriş merkezleri ülke genelindeki üretim mekânından tüketim mekânına dönüştürülen işletmelere (yapılara) örnek oluşturmaktadır (Tablo 1).

Tablo 1. Seçilmiş örnekler ile Türkiye'de AVM'ye dönüşen fabrikalar.

Table 1. Factories turning into malls with selected samples in Turkey.

\begin{tabular}{cccc}
\hline Bulunduğu il & Fabrika & AVM & AVM'nin açılış yılı \\
\hline istanbul & Profilo & Profilo & 1997 \\
Ankara & Et Balık Kurumu & AnkaMall & 1999 \\
istanbul & Philips Televizyon & Metrocity & 2003 \\
istanbul & Eczacıbaşı Illaç & Kanyon & 2006 \\
istanbul & Edip İplik & 212 & 2009 \\
Istanbul & Altınyıldız & Starcity & 2010 \\
Denizli & Sümerbank & Sümerpark & 2011 \\
Kayseri & Meysu & Meysu Outlet & 2011 \\
Hatay & Ak-iş & Palladium & 2013 \\
Istanbul & Roche Ilaç & Özdilek Park & 2014 \\
Istanbul & Ford & Akasya & 2014 \\
Çanakkale & Tekel Kanyak & 17 Burda & 2015 \\
Hatay & Meyankökü & Park Forbes & 2016 \\
Istanbul & Hasel & Axis & 2016 \\
Istanbul & Evyap & Vadistabul & 2017 \\
Isparta & Yün ve İlik & Şehir & 2018 \\
Adana & Tekel Sigara & Esas 01 Burda & 2019 \\
\hline
\end{tabular}

1 i̇stanbul'un söz konusu önemini ortaya koyan bir çalışma, Ayik tarafindan 2018 yılında "Ekonomi Politikalarının bir yansıması olarak sanayisizleşme ve mekânsal değişim: Istanbul örneği” başlığıyla ele alınmıştır. 
Bir dönemin üretim mekânları olan fabrikaların yıkılması veya restore edilmesi sonrasında tüketim mekânlarına/alışveriş merkezlerine dönüştürülmesi süreçlerinin yaşandığı illerden biri de Hatay'dır. Nitekim önemli bir liman kenti olan İskenderun'da tarihi meyankökü fabrikası yıkılarak bu fabrikanın yerinde 2016 yılında Park Forbes AVM hizmet vermeye başlamıştır. Diğer yandan, il merkezini oluşturan Antakya'da, uzun yıllar hizmet veren Ak-iş iplik fabrikası 2007 yılında yıkılarak bu fabrikanın yerinde Palladium AVM inşa edilmiştir (Şekil 1). Bu çalışmanın motivasyonunu; "fabrikaya yönelik aidiyet duygularına sahip üreten bir toplumdan, alışveriş merkezinin misafirleri durumundaki tüketen bir topluma geçiş sürecinde kentsel mekân nasıl şekillenmektedir?" sorusu oluşturmaktadır. Hizmete girdiği 1950'li yıllarda Hatay'ın en büyük üretim merkezi olan Ak-iş iplik fabrikası zamanla işlevini yitirerek yıkılmış ve onun yerine bir alışveriş merkezi inşa edilmiştir. Emek gücünden sermaye birikimine doğru gerçekleşen bu dönüşümün Antakya kentsel mekanını nasıl şekillendiğini ampirik analizlerle ortaya koymak bu çalışmanın amacını oluşturmaktadır.

\section{Materyal ve Metot}

Modernizmden postmodernizme geçiş süreçlerini üretim, üretimin durması, köhneleşme ve mekânın işlevsel dönüşümü olmak üzere geçmişten günümüze aşamalı olarak ortaya koyan bu çalışmada öncelikle modern/modernizm ve postmodern/ postmodernizm kavramlarını ve bu kavramların mekân ile ilişkilerini konu alan çalışmalara yönelik literatür taraması yapılmıştır. Literatürden elde edilen bilgiler doküman analizine tabi tutulmuştur. Çalışmada, bugünkü Palladium AVM'nin yerinde bir dönem iplik fabrikası olarak hizmet veren Ak-iş fabrikasının üretim mekânı olarak önemini ve fabrikanın mekân kullanımına etkilerini ortaya koyabilmek için Harita Genel Müdürlüğü’nden Antakya'nın geçmiş yıllara ait ortofoto görüntüleri temin edilmiş ve ayrıca resmî gazete arşivlerinden yararlanılmıştır.
Bu çalışmada hem nicel hem de nitel verilerin birlikte değerlendirilmesi anlayışını benimseyen karma yöntem kullanılmıştır. Nicel veriler yazarlar tarafindan belirlenen bir ölçek vasıtasıyla günümüz tüketim toplumunu yansıtması bakımından Antakya'daki Palladium AVM'ye giden yerel halktan toplam 265 kişiye uygulanarak toplanmıştır. Nitel veriler ise üretim sürecinin neden ve nasıl gerçekleştiğine yönelik keşfedici sorularla Ak-Iş iplik fabrikasından emekli olmuş 5 kişiyle gerçekleştirilen derinlemesine görüşmelerden elde edilmiştir. Fabrikanın aktif olduğu dönemlerdeki kentsel mekân ve üretim süreçleri; tarihi hava fotoğrafları, resmi gazeteler ve belgeler yardımıyla açıklanmıştır. Anket ve mülakat formları, Hatay Mustafa Kemal Üniversitesi Rektörlüğü Sosyal ve Beşeri Bilimler Bilimsel Araştırma ve Yayın Etiği Kurulu tarafindan incelenmiş ve ilgili kurulun 03.05.2021 tarih ve 07/12 sayılı kararınca formların uygulanması uygun görülmüştür. Anket formu uygulanırken COVID-19 salgınının tüketicilerin tutum ve davranışlarını (ziyaret sıklığı, alışveriş tercihi, harcama miktarı gibi) etkilemiş olduğu düşüncesinden hareketle bazı sorularda ankete katlanlardan salgından önceki dönemleri dikkate almaları istenmiştir. Salgın nedeniyle anketlerin yüz yüze gerçekleştirilmesi mümkün olmadığı için, anketler elektronik ortamda hazırlanmış ve uygulanmıştır. Veriler IBM SPSS_26 ve MAXQDA 2020 yazılımları kullanılarak analiz edilmiştir. Sorulara verilen yanıtlara yönelik olarak tablo ve grafikler hazırlanmış ve yorumlanmıştır. Çalışmadaki haritaların çiziminde ArcMap 10.3 paket programı kullanılmıştır.

\section{Bulgular}

\subsection{Modernizmin Üretim Mekânı: Ak-isş İplik Fabrikası}

Kent mekânının üretim, yeniden üretim ve dönüşümünde sermaye birikim süreçleri önemli bir rol oynamaktadır. Kapitalizmin gelişim sürecinde, mekânın kendisi metalaşmış ve sermaye biri-

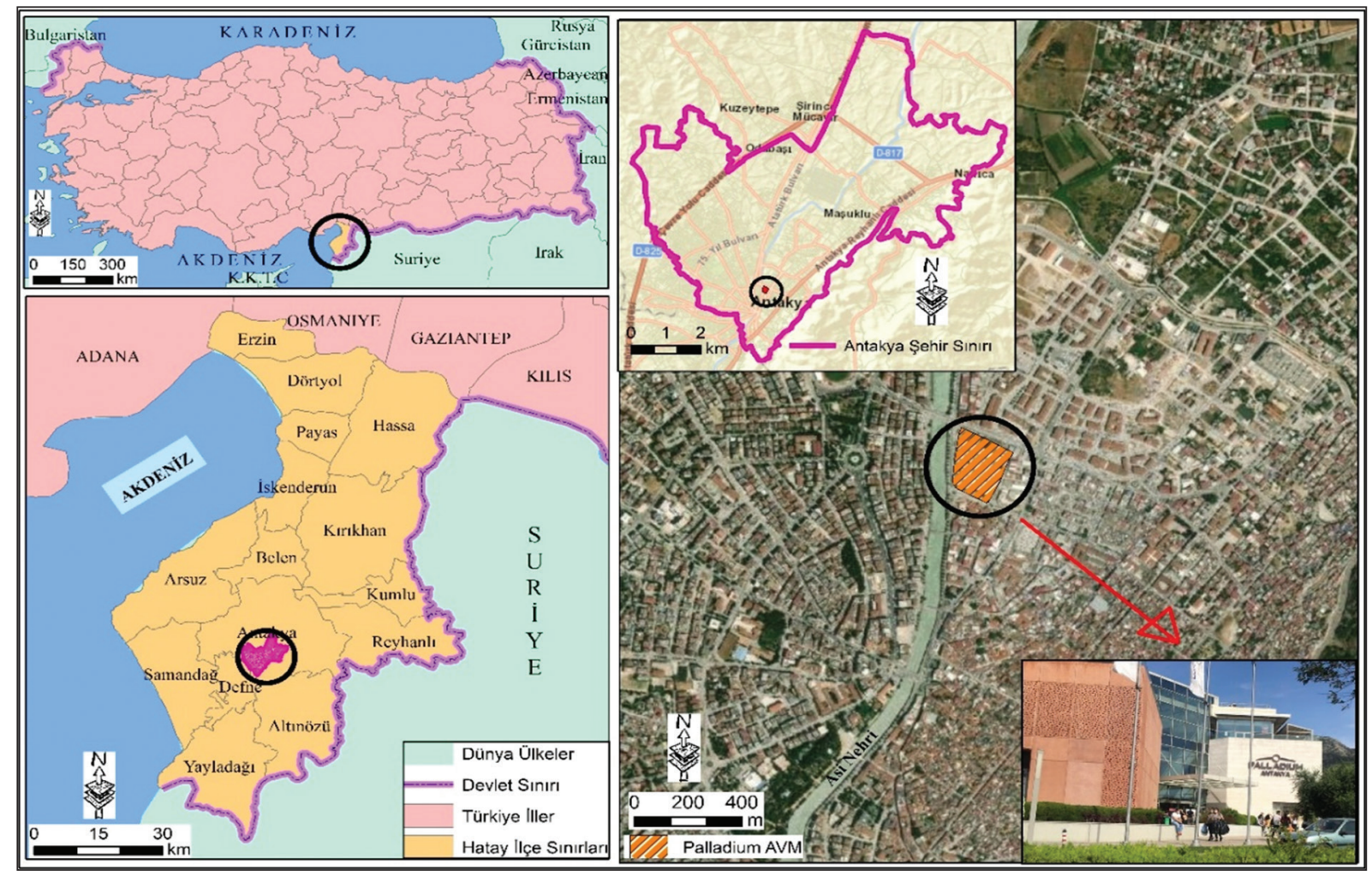

Şekil 1. Lokasyon haritası.

Figure 1. Location map. 
kim süreçleri açısından yaşamsal bir önem kazanmıştır (Şengül, 2009). Türkiye için $1920^{\prime}$ lerden 1980 'lerin sonlarına kadar uzanan dönem dış dünya ile olan ilişkiler ve değişik sosyal grupların yönetimdeki etkileriyle şekillenen ekonomik politika seçmeleri ile tanımlanan dönemlere ayrılmaktadır (Eraydın, 1988). Cumhuriyetin ilan edilmesinden 1950'lere kadar olan dönem, tarımsal üretimin ağırlıklı olduğu ve genellikle farklı politikalara dayalı olarak sanayi oluşturma dönemi olarak karakterize edilmektedir. "Ulus-devletin kentleşmesi" olarak adlandırılan bu dönemde kentler, tarımsal birikimin üretken sektörlere, diğer bir değişle sanayiye aktarıldığı bir sermaye birikiminin dönüşüm alanı olarak ortaya çıkmıştır. "Emek gücünün kentleşmesi" olarak tabir edilen 1950-1980 devresinde ise, daha önceki dönemlerden farklı olarak sermaye birikiminin artk oluşmuş olduğu ve kentlerin sermaye birikimi açısından yeni işlevler kazandığı dikkati çekmektedir (Tümertekin, 1973; Eraydın, 1988; Eraydın, 1992; Işık, 2005; Şengül, 2009; Keleş, 2015; Uğur \& Aliağaoğlu, 2018). Belirtilen dönemde ülkemizde kırdan kente gerçekleşen göçlerin hız kazanması kentsel mekânların da hızlı bir şekilde dönüşmesini beraberinde getirmiştir (Belge, 2018).

Sermayenin kentleşmesi olarak adlandırılan sürecin başladığı 1980 'li yıllardan itibaren, sermaye endüstriyel üretimden doğrudan üretkenliği olmayan gayrimenkul, finans ve turizm gibi alanlara aktarılmış, böylece sermaye, kentsel mekânların üretilmesi, yeniden yapılanması ve dönüştürülmesi süreçlerinde belirleyici etkilere sahip olmuştur (Eraydın, 1988; Şengül, 2009; Ayşın \& Turhanoğlu, 2014). Böylece postmodernizmin en önemli tüketim mekânlarından olan alışveriş merkezleri (AVM), birer üretim mekânı olan fabrikaların yerini almaya başlamıştır. Ülkemizin özellikle büyükşehirlerinde bu işlevsel dönüşümün çok sayıda örneği bulunmaktadır.

Hatay ili genelinde 1950 'li yıllara kadar tarımın diğer sektörlere egemen bir yapısı bulunmaktaydı. Bu tarihten sonra enerji sorununun çözülmesine bağlı olarak ildeki sanayi faaliyetleri gelişme sürecine girmiştir. Illk olarak yörede üretilen pamuğun yeni kurulan dokuma fabrikalarında işlenmesi söz konusu olmuştur (Çalışkan, 2002). Böylece Hatay, 1950'lerde bir pamuk bölgesi haline gelmeye başlamıştır. Toprak verimliliği bakımından Amik Ovası'nda yetişen pamuğun Adana'da dahi yetiştirilmediği belirtilmiştir. Burada, dönüme 150-200 kg’a kadar pamuk alınırken, Adana'da 30-40 kg alındığı bilinmektedir. ${ }^{2}$ Hatay'ın ve dolayısıyla Amik Ovası'nın pamuk üretimi bakımından taşımış olduğu önemin anlaşılması üzerine, Hatay'da bu pamuğu işleyecek bir endüstri tesisini kurma arayışları içerisine girilmiştir (Fotoğraf 1).

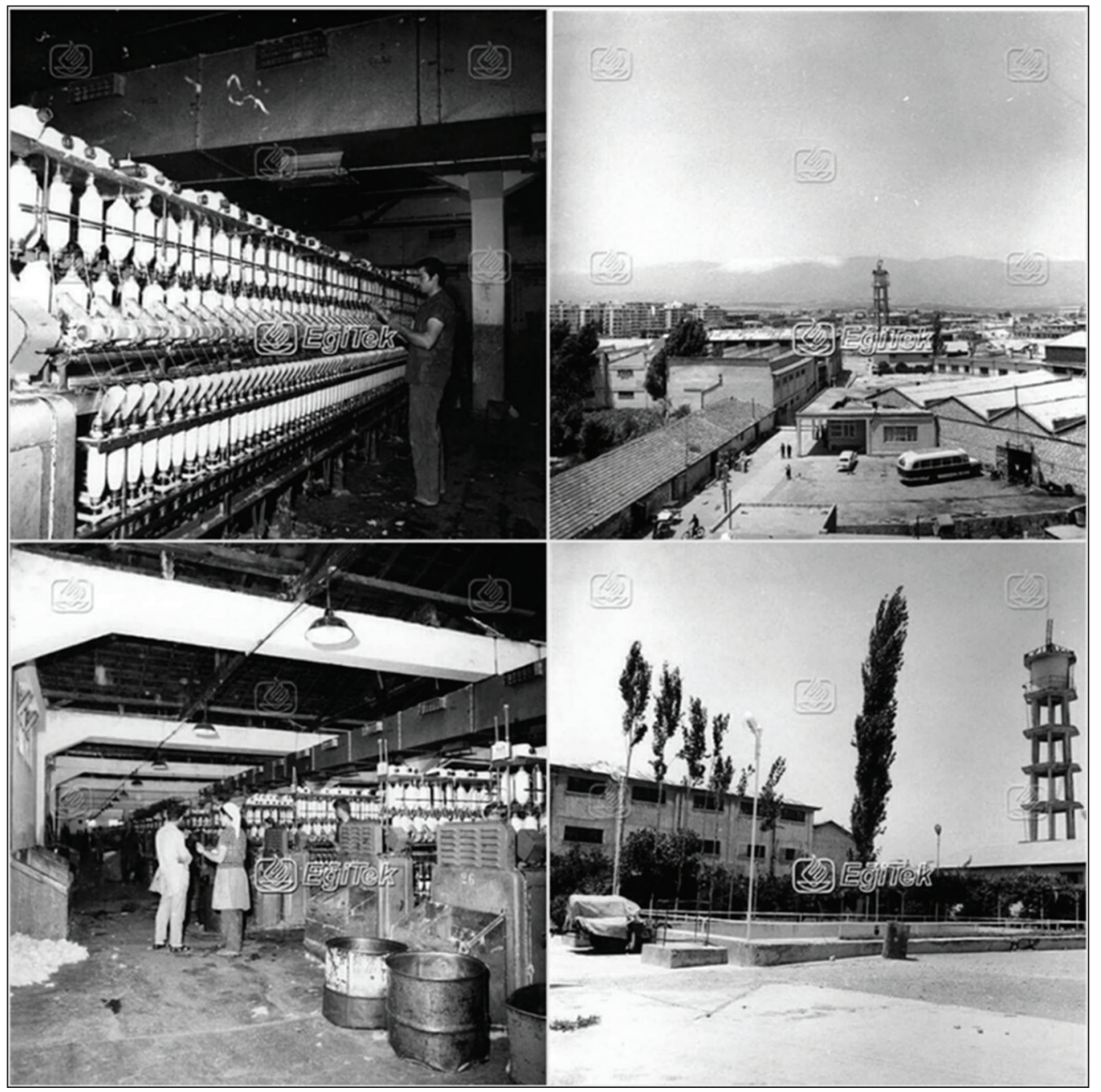

Fotoğraf 1. Ak-Iş̧ İplik Fabrikasından Görünümler³.

Photo 1. Images from Ak-Iss yarn factory.

2 TBMM Zabıt Ceridesi, B:54, 27.2.1949, O:2, s. 875

3 https://www.instagram.com/p/CK7M1R2HMlp/?utm medium=copy link, Erişim Tarihi, 10.06.2021. 
Bir tekstil fabrikası olarak 12 milyon sermaye ile 1954 yılında kurulmuş olan Ak-iş iplik fabrikası, yaklaşık 800 işçiye istihdam sağlamıştır ${ }^{4}$. Fabrikanın kurucusu olan Nuri Has'ın oğlu Kadir Has, 1950'li yılların başında Türkiye'de sanayileşme hamlesinin başladığını belirtmiş ve Ak-Iş fabrikasının kuruluş sürecini de şu şekilde anlatmıştır: "Babam yeni yatırımları için çevre ve piyasa etüdüne girişmişti. O yıllarda Antakya yöresinde işçi ücretleri çok düşüktü. Ayrıca o yörede yetiştirilen pamuk elyafi ise, Adana pamuğundan daha kaliteli idi. Babam bu avantajları göz önüne alarak, Antakya'da Ak-Iş iplik fabrikasını kurmaya karar verdi". 5

Hatay'da bir iplik fabrikasının kurulmasında etkili olan söz konusu faktörlerin yanı sıra ulus-devlet anlayışının da etkileri olmuştur. Şengül, (2009)'ün belirttiği gibi ulusal düzeyde ulus-devlet oluşturulmasının en önemli mekânsal öğelerinden biri anavatan düşüncesidir (Şengül, 2009). Hatay'ın 23 Temmuz 1939 tarihinde anavatana katılmasından önceki dönemlerde önemli bir sanayi yatırımı söz konusu olmamış, 1927 yılına ait sanayi ve işyerleri sayımında da Hatay ile ilgili kayıtlar tutulmamıştır (Doğanay \& Çavuş, 2011). Hatay'ın ulusal sınırlarımız içerisinde yer aldığı 1939 yılı ve sonrasında sanayi yatırımları kendisini göstermeye başlamıştır. Hatay'ın il merkezi durumundaki Antakya'da Ak-Iş adında bir iplik fabrikasının kurulması düşüncesinde ulus-devlet anlayışının önemli bir rol oynadığı, fabrikanın kurucularından Nuri Has'ın, dönemin cumhurbaşkanı olan Celal Bayar ile sohbeti sırasında kullandığı ifadelerden de anlaşılmaktadır. Bayar'ın, fabrikanın kuruluş sebebini sorması üzerine Nuri Has: "Muhterem Reisicumhurum. Bu topraklar bizim olmasa gelip para saçar mıyım? Artık bu toprakların bize ait olduğunu yaptiğım yatırımla Suriyelilere göstermek istiyorum. Burada yaşayan vatandaşlarımız da, benim yatırımımdan sonra iyice inandılar ki; artık burası Türk toprağı. Burada Türklerin fabrikaları dahi var 6 ." cevabını vermiştir.

Antakya'da üretim süreçlerinin mekân üzerindeki etkilerini ortaya koyabilmek için öncelikle sermaye birikiminin yapılı çevreyi nasıl şekillendirdiğini anlamak gerekir. Lefebvre, (1976)'e göre; sermaye birikimi, endüstriyel üretim süreçlerinde "mekânı işgal ederek ve mekânı üreterek" kendisini somut bir şekilde göstermiş ve bu sayede mekân üzerinde önemli değişim ve dönüşümler meydana gelmeye başlamıştır (Lefebvre, 1976). Lefebvre, üretim süreçlerinin mekânda üretilen metalardan (ürünlerden) mekânın kendisinin de meta olarak üretildiği bir aşamaya geçtiğini vurgulamıştır. Üretim kavramı, doğrudan sanayi ürünlerinin üretiminin yanı sıra yapılı çevrenin de üretilmesi süreçlerini kapsamıştır (Lefebvre, 2003; Lefebvre, 2015). Böylece kentlerin teşekkülü ve zamanla geçirdikleri yapısal değişimler, üretim süreçlerindeki değişimlere bağlı olarak meydana gelmiştir (Laçiner, 1996).

Antakya'da 1954 yılında Ak-iş iplik fabrikasının kurulmasıyla birlikte mekân kullanımında dikkate değer değişimler meydana gelmiştir. Fabrikanın kurulduğu yıllarda, Antakya Atatürk stadyumunun" 200 m güneybatısında "Akevler" adında işçi konutlarının inşa edilmesiyle mekânın şekillenmeye başladığı anlaşılmaktadır. Bu işçi konutları, Antakya'nın 1964 yılına ait hava fotoğrafinda görünmektedir (Fotoğraf 2). Çevresi geniş tarımsal arazilerden oluşan konutların yapılmasından sonraki süreçte nüfusun hızla artmasına bağlı olarak Akevler, Antakya'nın bugünkü merkez mahallelerinden biri olarak gelişme göstermiştir. Ak-iş iplik fabrikası, 2007 yılında yıkılarak tarih sahnesinden silinmiş olsa da Akevler Mahallesi bir yerleşme adı olarak varlığını günümüzde de sürdürmektedir. Böylece Akevler adı, bir dönemin üretim toplumu ve anlayışını yansıtan bir bellek olarak kalmış, ürünlerin kent mekânında üretilmesi süreçleri yerini mekânın üretilmesine bırakmıştır.

Tarım ve tarıma dayalı sanayi faaliyetlerindeki gelişmelere bağlı olarak 1950'li yılların ortalarında, Hatay'ın Yayladağı ve Altınözü ilçelerinden Antakya kentine yoğun bir göç olayı yaşanmıştır (Çetin, 2012). Şüphesiz bu göçler üzerinde 1954 yılında kurulmuş olan ve önemli bir istihdam sağlayan Ak-iş̧ iplik fabrikası da etkili olmuştur. Nitekim göçlerin, fabrikanın kurulmasından birkaç yıl sonra gerçekleşmeye başlaması, bu durumu destekler niteliktedir. Antakya şehrine yönelik gerçekleşen göçler, bugünkü gecekondu mahallelerinin kurulup gelişmesine neden olmuştur (Fotoğraf 2). Bağrıyanık, Aydınlıkevler, Şirince, Karaali Bölüğü, Hacı Ömer Alpagot mahalle muhtarlarıyla gerçekleştirilen görüşmelerde fabrikanın şehre yönelik göçleri etkileyen en önemli faktörlerden biri olduğu belirtilmiştir.

Antakya'da gecekondulaşmanın, Ak-iş fabrikasının kuruluşunu takip eden yıllarda meydana gelmesi ve gecekondularda yaşayan nüfusun zamanla artması yeterli sayıda ve ucuz işgücü teminini kolaylaşttrmıştır. Nitekim önceden de belirtildiği gibi ucuz işgücü fabrikanın kuruluş yeri seçiminde de etkili olmuştur. Fabrikanın kurulmasından sonra gecekondu alanlarında nüfusun hızla artması neticesinde Antakya Belediyesi sınırları içerisine dâhil edilen gecekondu mahallelerinin sayıları artmıştır ${ }^{8}$. Günümüzde Habib-i Neccar Dağı eteklerinde ve kente hâkim bir konumda yer alan bu gecekondu mahalleleri, "emek gücünün kentleşmesi” süreçlerinin (1950-1980) adeta birer kanıt durumundadır.

\subsection{Kentsel Çöküntü Alanı: Ak-İ̧̧ Fabrikasının İşlevini Yitirmesi ve Yıkılması}

Ak-iş iplik fabrikası kurulduktan sonra yaklaşık 15 yıl faaliyet göstermiş, 1968 yılında ekonomik problemlerden dolayı üretim durmuştur. Birkaç yıl sonra yeniden açılan fabrika 1979 yılında bir daha açılmamak üzere tamamen kapanmıştır. Antakya halkı için önemli bir kazanç kaynağı olan fabrikanın üretimini durdurması, fabrikada çalışanların işsiz kalmalarına neden olmuştur. Fabrika, üretimin durmasının ardından yaklaşık 30 yıl işlevsiz (atıl, harabe) durumda kalmıştır. Literatürde "brownfield" olarak adlandırılan yapıların bir örneğini teşkil eden fabrika sahası, kentin merkezinde sağlıksız ve güvenliği olmayan bir kentsel çöküntü alanı olarak kalmıştır. Bu alan, Antakya'nın 1995 yılına ait 1:25.000 ölçekli topoğrafya haritasında (P36-d2), "Çırçır Fabrikası (Çalışmıyor)" şeklinde gösterilmiştir (Harita Genel Müdürlüğü, 1995).

\footnotetext{
4 Cumhuriyet Gazetesi, 19.10.1968.

5 Sabah Gazetesi, 21.03.2002.

6 Sabah Gazetesi, 21.03.2002.

7 Tarihi Antakya Atatürk Stadyumu, Ekim 2021 itibariyle yıkılmış olup onun yerine Millet Bahçesi'nin yapılması planlanmaktadır.

8 Cumhurbaşkanlığı Cumhuriyet Arşivleri Başkanlığı, Fon Kodu: 30-11-1-0, Yer:297-9-15, Tarih: 28.03.1963. “Bağrıyanık Mahallesinin Antakya Belediyesi Sınırları İçerisine Alınması".
} 


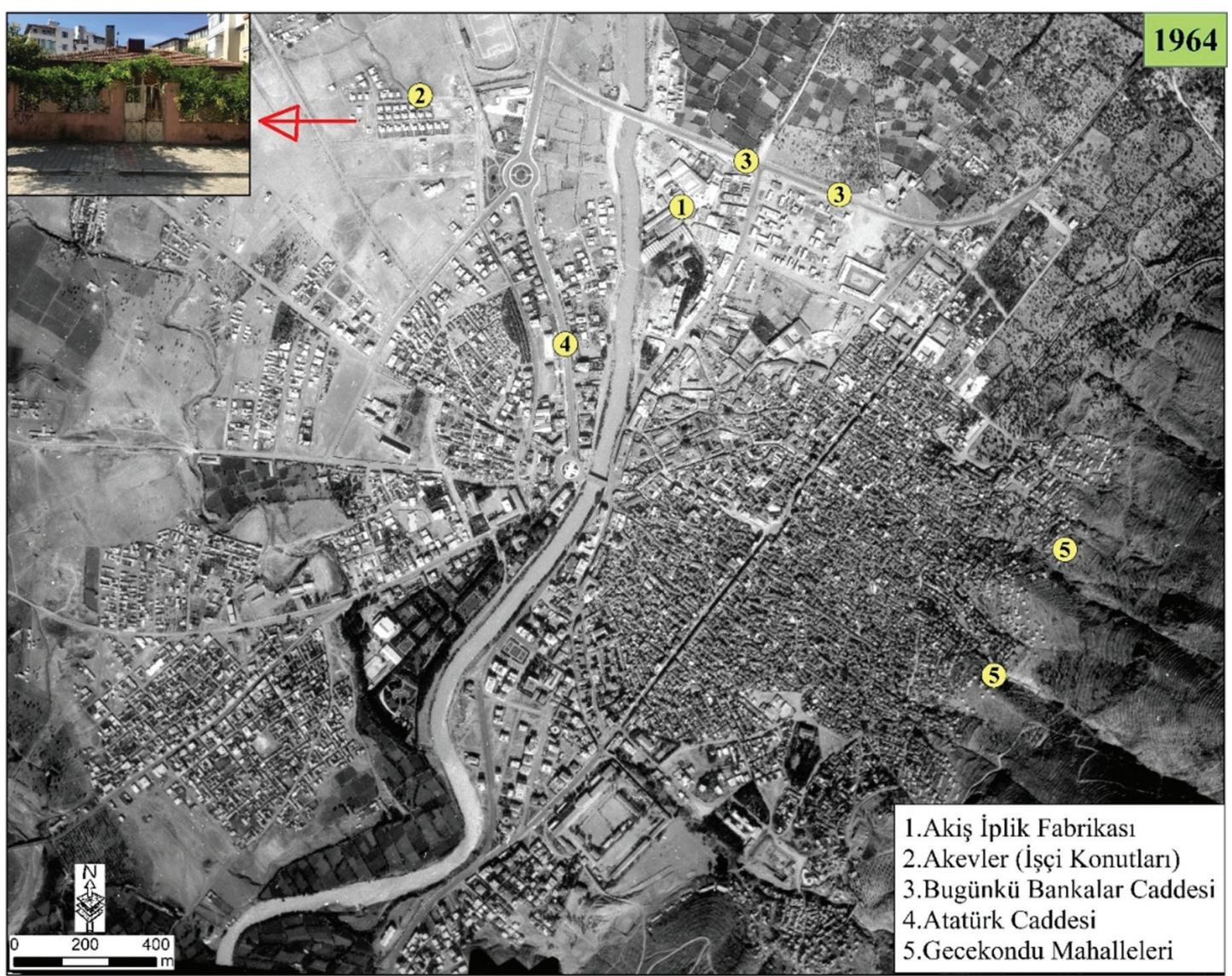

Fotoğraf 2. Antakya'nın 1964 Yılı Ortofoto Görüntüsü (Kaynak: HGM).

Photo 2. Orthophoto view of Antakya in 1964 (Source: HGM).

Fabrika emeklilerinden ve diğer yerel halktan elde edilen bilgilere göre, fabrikanın işlevini yitirmesi ve harabe haline dönüşmesiyle birlikte fabrika çevresinde özellikle akşam saatlerinde sık sık çeşitli suçların işlenmeye başladığı ve fabrikanın madde bağımlılarının uğrak yeri olduğu belirtilmiştir. Uzun yıllar kentsel çöküntü alanı olarak kalan fabrikanın çevresinde oldukça güvensiz bir ortamın oluşması, fabrikanın konumuyla da yakından ilişkili olduğu anlaşılmaktadır. Nitekim fabrikanın, gündüz oldukça hareketli olan ve gece tamamen sessizliğe bürünen Antakya merkezi iş alanının (Tarihi Antakya Çarşısı) bitişiğinde yer alması bu durumu destekler niteliktedir. İkametgâh sahalarından farklı olarak fabrika çevresinde daha çok ticari işletmelerin yoğun olması, özellikle akşam saatlerinde bir sessizliğe neden olarak suç oranlarının daha da artmasına ortam hazırlamıştır.

Ak-iş iplik fabrikası uzun yıllar ayakta kaldıktan sonra, 2007 yılında yıkılmış, fabrika sahası bir süre boş bir arazi olarak kalmış ve daha sonra bu arazi üzerinde bugünkü Palladium alışveriş merkezi inşa edilmiştir. Sağlıksız ve güvensiz bir ortama sahip olan fabrikanın yerinde 2013 yılından itibaren Palladium alışveriş merkezinin hizmet vermeye başlaması güvenlik kaygılarının azalmasını sağlamıştır. Nitekim Antakya çarşısına oldukça yakın bir konumda yer almasına rağmen, Palladium alışveriş merkezinin akşam saat 22:00'e kadar açık olması, güvenlik personelleri ve kameralarla 24 saat korunması ve AVM çevresinin yeterli düzeyde aydınlatılması güvenliği arttıran başlıca faktörler olmuştur.

\subsection{Postmodernizmin Tüketim Mekânı: Palladium AVM}

Ortaya çıkışından itibaren taşıdığı anlam sürekli tartışılagelen postmodernizm, özünde modernizme tepki olarak doğmuş bir paradigmadır. Postmodern mekân ve kentler ise, postmodernizmin pratikteki yansımasının ilk görüldüğü somut örneklerdendir. Kentsel mekân, modernizmde olduğu gibi, postmodernizmin etkilerinin görüldüğü odak noktalardan birini oluşturur. $\mathrm{Bu}$ açıdan tüketim kültürünü ön planda tutması nedeniyle postmodernizmle birlikte mekânın tüketim odaklı şekillenmeye başladığını söylemek mümkündür. Böylece literatürde, postmodernizm denkleminde mekan-tüketim kültürü ilişkilerini ortaya koyan ve coğrafyada yeni gelişen bir disiplin olan "tüketim coğrafyaları" başlıklı çalışmaların sayısı artış göstermiştir (Goss, 2004; Goss, 2006; Logemann, 2009; Mansvelt, 2010; Agarwal vd., 2017).

Postmodernizmin belirleyici aktörlerinden olan tüketim kültürü, postmodern kentin merkeziyetini oluşturmaktadır. İçinde bulunduğumuz tüketim kültürünün kentlere olan etkileri postmodern mekânlarda açık bir şekilde gözlemlenebilmektedir. Zira postmodern kent, haz tüketimine dayalı kent formudur (Mullins, 1991). Postmodernizmin merkezine oturan tüketim endüstrisi, toplumun her bir düzeyi için ayrı önerilerde bulunurken, insanların çalışma dışındaki boş zamanını nasıl geçirmeleri gerektiğine dair yeni alternatifler de sunmaktadır. Dinlenebilmenin çeşitli alternatifleri içerisinde tüketime dayalı aktiviteler ön plana çıkmakta, işten arta kalan zamanların art değer oluşturması için bireyler tüketime yönlendirilmektedir (Batu \& Tos, 2017). Böylece kentler, endüstrilerden arındırılıp birer tüketim merkezi hâline dönüşmüştür (Featherstone, 2013).

Özgün bir kültürün uzantısı olan postmodern yaşam tarzı mekân tasarımına da yansımıştır (Veril, 2006). Bu yansımanın somut örneklerinden birini de alışveriş merkezleri oluşturur. 
Gerçekten de alışveriş merkezleri postmodern toplum anlayışını simgeler (Korkusuz, 2020). Gottdiener, (2005) alışveriş merkezlerinin tüketim mallarının satıldığı mekânlar olduğunu ifade ederek, bu mekânların temel amaçlarının tüketim faaliyetlerini kolaylaştiran bir imaj sunmak olması nedeniyle birer postmodern gösterge olarak nitelendirilmeleri gerektiğini belirtir (Gottdiener, 2005). Bununla birlikte büyük nüfus kitlelerini ikame edebilecek tüketim mekânları olan alışveriş merkezleri postmodern mekânın kent dokusunu şekillendirmektedir (Kaygalak \& Işık, 2007).

Dünya'daki ilk örneklerinin 1950'li yıllarda Birleşik Devletler'de (Mall of America, Disneyworld gibi) görülmeye başlandığı alışveriş merkezleri, Türkiye'de 1980'li yılların ikinci yarısından itibaren açılmaya başlamıştır. Bu durumun ortaya çıkmasında, Türkiye ekonomisinin 1980 sonrasında geçirdiği yapısal değişim önemli bir rol oynamıştır. 24 Ocak 1980 kararları ile dışa açık ekonomi politikalarına önem veren Türkiye'de, 1980 sonrası dönemde benimsenen neoliberal politikalar sonucunda sermaye, mekânı şekillendirmeye başlamıştır. Bu durumun somut örnekleri arasında söz konusu dönemde inşa edilmeye başlanan tematik oteller, güvenlikli/lüks siteler içerisindeki yüksek katlı konutlar, rezidanslar, ulus ötesi şirketlerin Türkiye mağazaları, tematik parklar ve alışveriş merkezileri gösterilebilir (Bat, 2007).

Türkiye kentlerinde yer alan alışveriş merkezleri kent mekânlarını etkileyen/dönüştüren unsurların başında gelmektedir (Erkip, 2003). Türkiye'de inşa edilen ilk alışveriş merkezi 1988 yılında faaliyete giren İstanbul-Ataköy'deki "Galleria" olmuştur. İstanbul'un ardından ilk olarak büyük kentlerde hizmete giren alışveriş merkezleri, 1990 'I yılların ikinci yarısından itibaren Anadolu'nun diğer kentlerinde de açılmaya başlamıştır (Timor, 2001). Alışveriş merkezlerinin Türkiye'deki serüveni sadece metropol kentler ile sınırlı kalmamıştır. Daha küçük kentler ve hatta kent statüsü taşımayan yerleşim birimleri bile alışveriş merkezleri ve beraberinde getirdiği tüketim kültürü ile tanışmıştır (Vural-Arslan, 2009). Bu kültür ile tanışıklık çok eskiye dayanmasa da Türk halkının alışveriş merkezlerini hevesle ve düzenli olarak kullanmaya hızla adapte olduğunu söylemek mümkündür (Erkip, 2003). Bu durumun somut örneklerini özellikle Anadolu'da alışveriş merkezi deneyimini ilk kez yaşayan kentlerde görmek mümkündür. Alan araştırmasının gerçekleştirildiği Antakya da söz konusu kentlerden biridir.

Hatay, tüketim kültürünün en önemli göstergelerinden biri olan alışveriş merkezleriyle 2010 yılında tanışmıştır. 2010 yııında İskenderun'da açılan Primemall alışveriş merkezi, Hatay'ın ilk alışveriş merkezi olarak hizmet vermeye başlamıştır. Göreceli olarak Türkiye ölçeğinde Hatay'ın alışveriş merkezleri ile tanışması geç gerçekleşirken izleyen altı yılda üç tane daha alışveriş merkezi faaliyete geçmiştir. Bugün il genelindeki toplam dört adet alışveriş merkezinin ikisi Antakya'da (Primemall Antakya, Palladium Antakya), diğer ikisi ise İskenderun'da (Primemall İskenderun, Park Forbes) yer alır. Bu araştırmaya konu olan Palladium Antakya AVM, 09.10.2013 tarihinde hizmete girmiştir. Palladium Antakya 95 mağaza 19 yeme-içme tesisi ve 12 sinema salonu ile hizmet vermektedir. ${ }^{9}$ (Fotoğraf 3 ).

Alışveriş merkezlerinin kuruluş yerleri seçilirken genellikle kentlerin kenar kesimleri ve gelişmiş otoyollara yakınlık tercih edilmektedir. Nitekim Antakya'da kurulan ilk alışveriş merkezi özelliğine sahip Primemall, Asi Nehri'nin batı yakasında, kentin yeni gelişim sahasında ve çevreyolu kenarında inşa edilmiştir. Yeni Otogar, TOKi ve Adalet Sarayı gibi yapıların da yer aldığı bu saha aynı zamanda "Yeni Antakya" olarak adlandırılmaktadır. Palladium AVM ise, Primall AVM'den ve diğer birçok alışveriş merkezinden farklı olarak Antakya'nın tarihi kent dokusunun

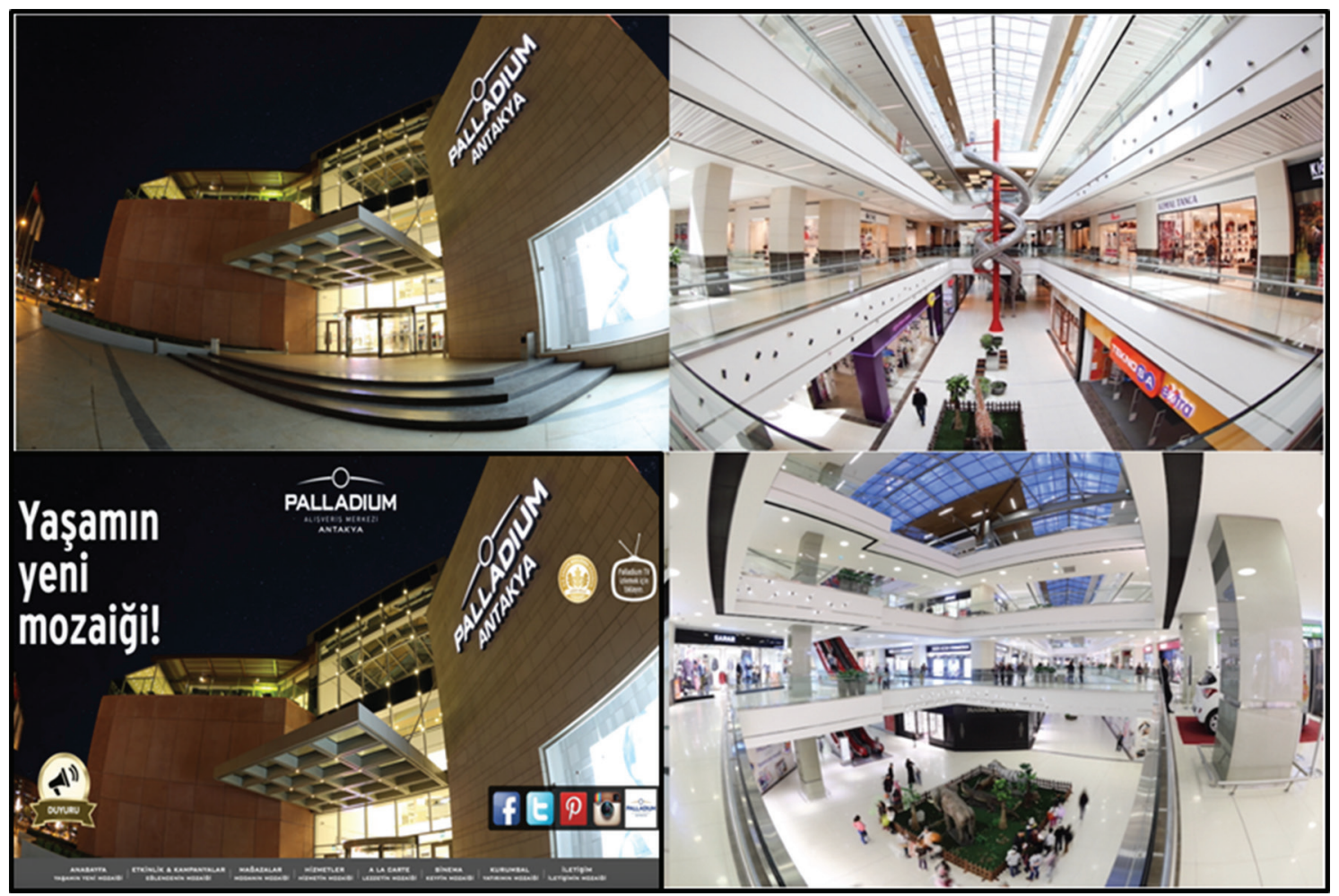

Fotoğraf 3. Palladium Antakya AVM9.

Photo 3. Palladium Antakya Mall9. 
(Eski Antakya) bitişiğinde kurulmuştur. Şüphesiz üretim mekânından tüketim mekânına gerçekleşen dönüşümünün tarihi kent dokusu içerisinde meydana gelmiş olması, kent dokusunun korunmasına yönelik hassasiyet gösterilmesini gerekli hale getirmiştir. Nitekim Palladium Antakya'nın web adresinde de alışveriş merkezi hakkında bilgi verilirken Antakya ile özdeşleşen "mozaik" kavramına ayrı bir vurgu yapılmıştır (Fotoğraf 3).

Eski Antakya'da yer alan geleneksel konutların belirgin özelliklerinin başında yörede bulunan taşlardan inşa edilmiş olmaları ve avlulara sahip olmaları gelmektedir. Baudrillard'ın perspektifinden değerlendirildiğinde alışveriş merkezlerinin kentlerin simülasyonu olarak inşa edildiği ve kent merkezlerine ait olan birçok özelliğin alışveriş merkezlerinin mimari özelliklerinde de kullanıldığı görülür (Şan vd., 2017). Bu noktada Palladium Antakya projesini gerçekleştiren Ergün Mimarlık bu projeyi şu şekilde anlatmıştır:

"Proje mümkün olduğunca parçalı bir şekilde ele alınarak ve üçüncü katta geri çekilerek çevresindeki binalarla arasındaki ölçek çatışması minimize edilmiştir. Binada konumlanmış avlular, bir yandan binanın doğal yolla havalanmasını sağlarken, bir yandan da bina kullanıcı için, serin açık mekânlar sunar. Bina cephesinde ağırlıklı olarak doğal ve yerel bir malzeme taşı olan Halep taşı tercih edilerek çevredeki tarihi kimlikle ilişki kurulmuştur."10

Palladium Antakya, kentsel mekânın ve kent içi dinamiklerin şekillenmesinde önemli bir rol oynamıştır. Alışveriş merkezi açılmadan önce, kentin önemli bir ticaret bölgesi olan Atatürk Caddesi'nde yer alan ticarethanelerin bir kısmının cadde mağazacılığından alışveriş merkezi mağazacılığına geçmeleri' ${ }^{11}$ bu duruma bir örnek oluşturmaktadır. Alışveriş merkezinin hizmete girmesinden önceki dönemlerde, marka değeri taşıyan mağazaların yer aldığı Atatürk Caddesi, çift şeritli (yönlü) ve nispeten geniş ulaşım hattyyla da Antakya'nın en işlek caddesi olarak dikkati çekmiştir. Ancak Palladium alışveriş merkezinin açılması ile birlikte çok sayıda mağaza Palladium’a taşınmış,
Atatürk Caddesi 2019 yılı sonuna kadar tek yönlü olarak hizmet vermeye başlamış ve eski canlılığını yitirmiştir ${ }^{12}$ (Fotoğraf 4).

Palladium alışveriş merkezinin inşa edilmesiyle birlikte geleneksel alışveriş kültürü ile postmodern alışveriş kültürünün bir arada yer aldığı farklı bir mekân kullanımı söz konusu olmuştur. Böylece İzzet Güçlü, İstiklal ve Yavuz Selim caddelerinde önemli bir hareketlilik görülmeye başlanmıştır. Postmodern tüketim anlayışının mekân kullanımı üzerindeki en belirgin etkilerinden biri, söz konusu caddeler üzerinden alışveriş merkezinin otoparkına doğrudan erişimin sağlanabilmesi olmuştur. Başka bir değişle tüketicinin alışveriş merkezinde daha uzun zaman geçirebilmesi için tasarlanan iç mekân anlayışının yanı sıra, tüketiciyi alışveriş merkezi ile buluşturacak bir ulaşım bağlantısı da kurulmuştur. Geleneksel Antakya çarşısında özellikle hafta sonları trafiğin yoğun olması, halkın hatta çarşı esnafinın alışveriş merkezi otoparkından yararlanmaları sonucunu doğurmuştur. Caddeler üzerinde araç park etmek ücretliyken, alışveriş merkezi otoparkının ücretsiz olması tüketicinin alışveriş merkeziyle buluşmasını teşvik etmektedir. Diğer yandan kent içi ulaşımı sağlayan otobüs hatları üzerine "Palladium" durağının eklenmesi ${ }^{13}$, tüketicinin alışveriş merkezine doğrudan erişimini kolaylaştırmıştır.

Tarihi Antakya çarşısının bitişiğinde kurulan Palladium'un mekân üzerindeki en belirgin etkilerinden bir diğerini arazinin daha fazla değer kazanması oluşturmuştur. Palladium çevresinde yer alan konut ve işyerlerinde "Palladium'a yakın olma özelliklerinin ön plana çıkarılması" 14 alışveriş merkezinin yakın çevresinde emlak piyasasının daha canlı olmasına neden olmaktadır. Ayrıca alışveriş merkezi çevresinde arazi rayiç değeri sürekli artş göstermektedir. Nitekim Palladium'un hizmete girmesinden önce, Yavuz Selim Caddesi'nde 2012 yılında metrekareye düşen rayiç değer 119 TL iken, AVM'nin açıldığı 2013 yılından 2021 yılına kadarki 8 yıllık dönemde bu değer yaklaşık iki kat artarak arazinin metrekare fiyat 222 TL olmuştur ${ }^{15}$.

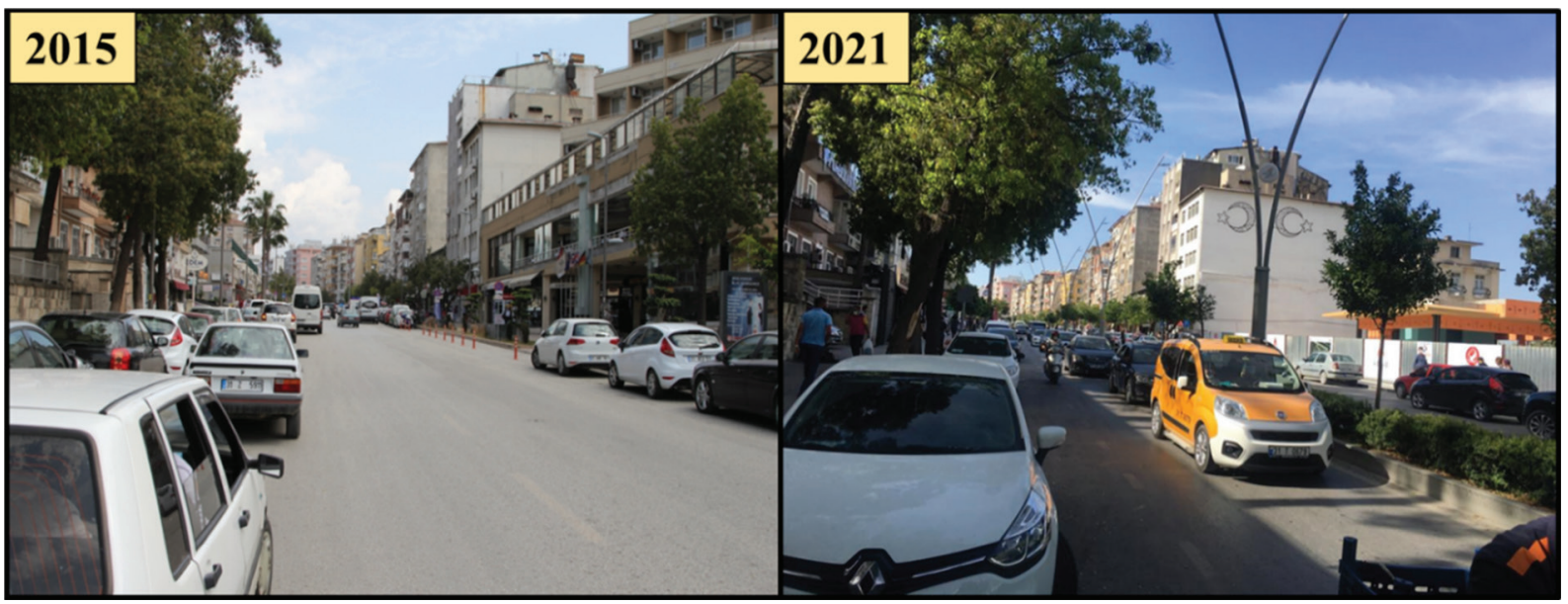

Fotoğraf 4. Atatürk Caddesi'nin 2015 ve 2021 yılları görüntüsü (soldaki fotoğrafta cadde tek yönlü, sağdaki fotoğrafta ise çift yönlü trafiğe açılmıştir). Photo 4. View of Atatürk Street in 2015 and 2021 (on the left photo, the street is opened to one-way traffic, and on the rigth photo the street is opened to twoway traffic).

\footnotetext{
10 https://www.ergunmimarlik.com.tr/proje-detay/PalladiumAntakya (Erişim tarihi 23.02.2021)

11 Palladium Antakya yetkileriyle yapılan görüşmede Atatürk caddesindeki işyeri sahiplerinin AVM içerisinde de dükkân açtıklarını belirtmişlerdir.

12 https://hataydikengazetesi.com/yine-basa-donduk/ (Erişim tarihi 25.05.2021)

13 https://www.hataykart.com/wheremybus (Erişim tarihi 23.02.2021)

14 Popüler satılık/kiralık emlak-işyeri platformlarından olan sahibinden.com ve hürriyetemlak.com web sitelerinde "Palladium Antakya" filtrelemesiyle yapılan arama sonucunda, "Palladium'a yakın olma özelliklerinin ön plana çıktı̆ı̆” ilanların birçoğunda alışveriş merkezini gören görsellerin yer aldığı tespit edilmiştir.

15 https://webportal.antakya.bel.tr/web/guest/5 (Erişim tarihi 14.06.2021)
} 
3.4. Alan Araştirması

\subsubsection{Nitel bulgular}

Bu çalışmada, Ak-iş iplik fabrikasının bir üretim mekânı olarak önemini ortaya koyabilmek için bu fabrikadan emekli olan 5 kişi ile yarı yapılandırılmış görüşme formları üzerinden derinlemesine görüşmeler gerçekleştirilmiş ve bu şekilde elde edilen nitel veriler yorumlanmıştır. Çalışmanın amacına uygun olarak elde edilen nitel bulgular üç temel temaya dayanmaktadır: emek gücü, kentsel bellek, mekân kullanımı. Mülakatların az kişiyle gerçekleştirilmesinin en önemli nedenini fabrikanın 1979 yılında tamamen kapanması, emeklilerin çoğunun günümüzde yaşamlarını yitirmiş olmaları ve yaşayanların ise 70 yaşın üzerinde olmalarıdır. Diğer yandan COVID-19 salgınının özellikle yaşlı nüfus üzerinde önemli bir risk oluşturması nedeniyle bazı fabrika emeklileriyle bir araya gelebilmek mümkün olmamıştır. Bu sınırılıklara rağmen 5 kişiyle gerçekleştirilen görüşmeler, bir üretim mekânı olarak fabrika hakkında genel bilgilerin elde edilebilmesini sağlamıştır.

Görüşmeye katılanlardan alınan bilgilere göre; 1954 yılında bugünkü Palladium alışveriş merkezinin yerinde hizmete giren Ak-iş fabrikası, Antakya'nın o yıllardaki en önemli fabrikası durumundaydı. Makinelerin hiç susmadığı ve günde 3 vardiya ile (08:00-16:00, 16:00-24:00 ve 24:00-08:00) işçilerin dönüşümlü olarak çalıştiğı fabrika, yaklaşık 800 iş̧̧iye iş imkânı sunmuştur. Fabrikadan emekli olanlar, çok küçük yaşlarda işe girdiklerini ve geçim sıkıntıları nedeniyle buna mecbur kaldıklarını belirtmişlerdir. Fabrikanın aktif olduğu yıllarda Antakya'nın âdeta bir sembolü olduğunu ifade etmişlerdir. Nitekim görüşmecilerden birine göre; o yıllarda "fabrikanın tepesinde bir deve heykeli vardı. Bu, şehrin her tarafindan görülürdü ve ışıklandırılmıştı. Akşamları ışıkları yanardı. Ayrıca fabrikada üretilen hammaddelerin üzerinde de deve figürü vardı." (Görüşmeci 2). Üretim süreçlerinde iş̧̧ilerin servislerle veya yaya olarak Antakya'nın dört bir köşesinden fabrikada çalışmaya geldikleri bilinmektedir. İşçilerin çoğunlukla Serinyol, Büyük Karaçay, Balıklıdere, Harbiye, Küçükdalyan, Turunçlu, Çekmece, Ekinci, Elektrik ve Armutlu 'da ikamet edenlerden oluştuğu belirtilmiştir.

Üretim ve tüketim mekânlarının fabrika emeklileri tarafindan nasıl algılandığını ve fabrikanın kentsel belleklerindeki yerini ortaya koyabilmek için görüşmeye katilanlara "Ak-iş iplik fabrikası ile bunun yerinde inşa edilen Palladium alışveriş merkezini karşılaştırabilir misiniz?" sorusu sorulmuştur. Katılımcılar fabrikanın önemli bir istihdam sağladığı konusunda ortak görüş belirtmişlerdir. Fabrikanın aktif olduğu yıllarda çok sayıda ailenin geçimlerini fabrikadan sağladıkları ve çalışarak birikim yaptkkları ifade edilmiştir. Bir görüşmeci bu konudaki düşüncelerini; "Fabrikada çalışmaya başladığım yıllarda babam emeğim boşuna gitmesin diye her ay altın alırdı ve bu şekilde birikim yapardım. Fabrika yaşayabilmek için bir kazanç kaynağıydı, alışveriş merkezleri ise bugünlerde kazandığını harcadığın bir yerdir." olarak ifade etmiştir (Görüşmeci 2).

Görüşmecilerin yaşlı nüfustan oluşmaları ve hareket kabiliyetlerinin büyük ölçüde azalmış olması, Antakya'nın bugünkü mekânsal yapısı hakkında bilgi düzeylerinin sınırlı olmasına neden olmuştur. Bu durum, görüşmecilere yöneltilen "Bir yer tarif ederken eski $A k$-işs iplik fabrikasının yer aldığı mekânı re- ferans olarak kullanıyor musunuz?" sorusuna verilen cevaplardan da anlaşılmaktadır. Bir görüşmeci bu konudaki düşüncelerini; "Fabrika, hem şehrin bilinen bir yeri olduğu için hem de fabrikada uzun yıllar çalıştı̆ım için bugün bir yer tarif ederken, mekân adı olarak Ak-iş fabrikasını kullanıyorum" olarak belirtmiştir (Görüşmeci 1). Bir başka görüşmeci ise "Bir yer tarif ederken fabrikayı referans gösteririm. Çünkü biz fabrikanın yerine alışmışız. Fabrikanın hayatımızda önemli bir yeri oldu." ifadesini kullanmıştır (Görüşmeci 3). Bir diğer görüşmeci ise uzun yıllar Ak-iş iplik fabrikasının yer aldığı mahallede ikamet etmiş olmaları nedeniyle fabrikanın kendi belleklerinde önemli bir yere sahip olduğunu ifade etmiştir. Bu görüşmeci düşüncelerini şu şekilde belirtmiştir: "Bir yer tarif ederken fabrikayı referans olarak gösteririm. Fabrika benim için önemliydi. Çünkü fabrikanın kurulduğu yıllarda Ada Mahallesi olarak bilinen yerde oturuyorduk. Ben buraya gelin gitmiştim. Bütün çocuklarım burada doğdu. Bu mahalle fabrikanın hemen arkasındaydı." (Görüşmeci 4).

Fabrikanın kurulmasının öncesinde ve sonrasında fabrika çevresinde mekân kullanımı bakımından meydana gelen değişiklikleri ortaya koyabilmek için görüşmecilere bir soru yöneltilmiştir. Bu soruya verilen cevaplardan hareketle fabrika çevresindeki mekân kullanımı anlaşılmaya çalışılmıştır. Fabrika inşa edilmeden önce yerinde herhangi bir yapının olmadığı, fabrika arazisinde ve yakın çevresinde geniş bahçe ve tarlaların yer aldığı ve bu saha içerisinde bir tabakhanenin hizmet vermekte olduğu ifade edilmiştir. Fabrikanın hizmet vermeye başlaması ile birlikte Ada Mahallesi'nde çok sayıda işyeri ve dükkânın inşa edildiği ve üretimin ilk yıllarında bugünkü gecekondu mahallelerinin henüz tam anlamıyla gelişmediği belirtilmiştir. Yine üretimin ilk yıllarında Antakya Atatürk Stadyumu'nun hemen bitişiğinde fabrikada çalışan ustalar ve şefler için "Akevler" adında lojmanların yapıldığı ve bu lojman evlerinin toplam üç sıra halinde (üç sokak) inşa edildiği belirtilmiştir. Fabrikanın kurulduğu 1950'li yıllarda Antakya'da Ak-Iş iplik fabrikası kadar büyük bir fabrikanın bulunmadığı, fabrikanın kapanmasından sonraki süreçte İskenderun yolu üzerinde Hateks adıyla bilinen iplik fabrikasının hizmete girdiği ifade edilmiştir. Ak-Iş̧ iplik fabrikasının kapatımasının ardından yıllarca bakımsız bir durumda kaldığı ve harabeye dönüşen fabrikaya müdahale edilmediği belirtilmiştir.

\subsubsection{Nicel bulgular}

Bu çalışmada, nicel veri toplama sürecindeki katılımcıların tümü "Antakya ve yakın çevresinde ikamet edenlerden" oluşmaktadır. Kişilerin Palladium AVM'ye erişimlerinin daha kolay olduğu düşünüldüğü için Antakya ve yakın çevresinde ikamet edenler seçilmiştir. Katlımcıların \% 65'i 18-25 ve 36-45 yaş aralığındadır. Bunlara 26-35 yaş grubunda olan katılımcılar ilave edildiğinde, ankete katılanların \% 88'inin 18-45 yaş aralığında olduğu dikkati çekmektedir (Tablo 2). Şüphesiz bu durum, postmodern tüketim kültürü ve alışkanlığının belirli yaş gruplarında toplanmış olmasıyla ilişsilidir.

Katılımcılar arasında Antakya doğumlu kişiler (158 kişi) ağırıktadır. Bu durumu destekler nitelikte, katılımcıların yarısından fazlası yirmi yılı aşkın süredir Antakya'da ikamet etmektedir. Söz konusu durum, incelenen nüfus kitlesinin ayırt edici bir özelliği olarak karşımıza çıkmaktadır ki, bu özellik katılımcıların 
Tablo 2. Katılımcıların demografik özellikleri.

Table 2. Demographic features of participants.

\begin{tabular}{|c|c|c|c|c|c|}
\hline Yaş & $f$ & $\%$ & Cinsiyet & $f$ & $\%$ \\
\hline $18-25$ & 86 & 32,4 & Kadın & 150 & 56,6 \\
\hline $26-35$ & 61 & 23 & Erkek & 115 & 43,4 \\
\hline $36-45$ & 86 & 32,4 & Toplam & 265 & 100 \\
\hline $46-55$ & 30 & 11,3 & Eğitim durumu & $f$ & $\%$ \\
\hline $56-65$ & 2 & 0,8 & İlköğretim & 13 & 4,9 \\
\hline Toplam & 265 & 100 & Lise ve dengi & 23 & 8,7 \\
\hline İkamet süresi & $f$ & $\%$ & Üniversite & 205 & 77,3 \\
\hline 1 yıldan az & 6 & 2,3 & Lisansüstü & 24 & 9 \\
\hline 2-5 yıl & 32 & 12,3 & Toplam & 265 & 100 \\
\hline $6-10 \mathrm{yll}$ & 25 & 9,6 & Doğum Yeri & $f$ & $\%$ \\
\hline $11-15$ yıl & 24 & 9,2 & Antakya & 158 & 59,6 \\
\hline $16-20$ yıl & 38 & 14,6 & Diğer & 107 & 40,4 \\
\hline $20+$ & 134 & 51,7 & Toplam & 265 & 100 \\
\hline Toplam & 259 & 100 & & & \\
\hline
\end{tabular}

Ak-Iş iplik fabrikasının çöküntü halindeki durumuna (brownfield) ve Palladium alışveriş merkezinin hizmet verdiği dönemlere tanıklık etmeleri açısından önemlidir.

Ankete katılanların yarısından fazlası AVM'ye ulaşımlarını özel araçlarıyla sağlamaktadır. Bu durumun bir neticesi olarak katlımcılar tarafindan Antakya ve çevresindeki en önemli sorunun büyük oranda trafikle ilişkili olarak belirtilmesi, her şeyden önce alışveriş merkezinin şehrin merkezinde (merkezi iş alanında) yer alması ile yakından ilişkilidir. Ayrıca önemli sorunlardan biri olarak belirtilen gürültü kirliliği de özellikle gündüz saatlerinde oldukça hareketli olan merkezi iş alanının yarattı- ğı bir durumdur. Palladium AVM'nin konumu genel itibariyle katılımcılar tarafindan beğenilmektedir. Diğer çeşitli çekiciliklerinin yanında konumunun da katılımcılar tarafindan uygun görülmesi AVM'nin tercih edilmesinde önemlidir. Böylesi bir durumda ise ulaşımda neden özel araçların tercih edildiği de sorgulanmalıdır. Şüphesiz Palladium AVM'nin ücretsiz kapalı katlı otopark hizmeti sunması özel araç tercihinde önemlidir. Nitekim gündelik hayatta çarşıya giden kişilerin hatta çarşı esnaflarından bazılarının AVM'nin otoparkını kullanmaları sıkça karşılaşılan bir durumdur. Öte yandan dikkati çeken önemli bir nokta ise güvenlik sorununun katilımcılar tarafindan en az (\% 1,5 ) işaretlenen seçenek olmasıdır (Şekil 2).
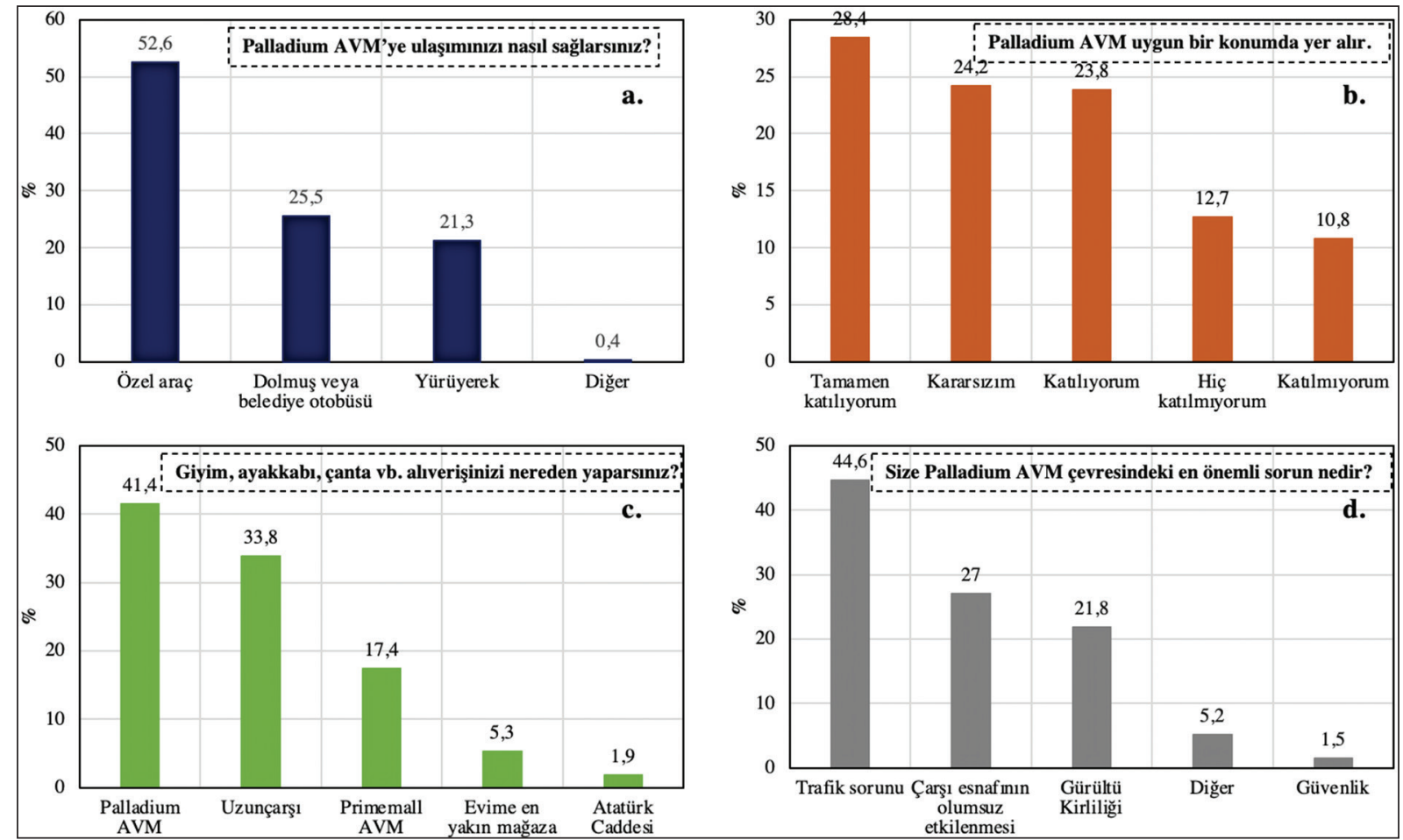

Şekil 2. Katılımcıların Palladium AVM'ye ilişkin çeşitli sorulara verdiği cevaplar.

Figure 2. The answers of the participants of to various questions about Palladium Mall. 


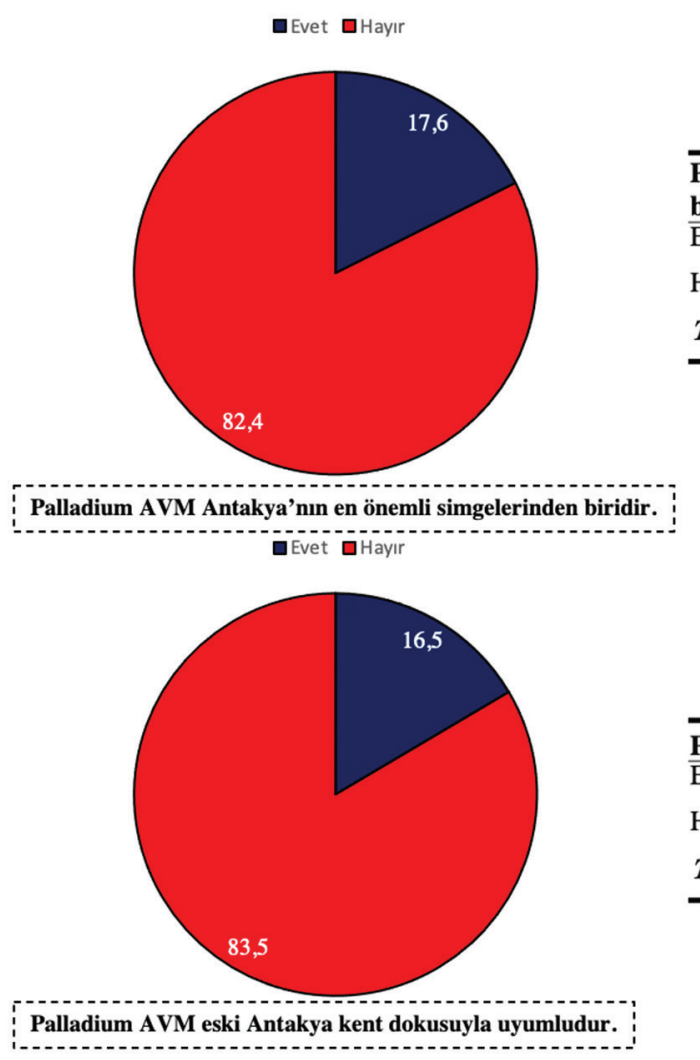

\begin{tabular}{lcc}
\hline $\begin{array}{l}\text { Palladium AVM Antakya'nın en önemli simgelerinden } \\
\text { biridir }\end{array}$ & f & $\%$ \\
\hline Evet & 46 & 17,6 \\
Hayır & 215 & 82,4 \\
Toplam & 261 & $\mathbf{1 0 0}$ \\
\hline
\end{tabular}

\begin{tabular}{lcc}
\hline Palladium AVM eski Antakya kent dokusuyla uyumludur & f & \% \\
\hline Evet & 43 & 16,5 \\
Hayır & 217 & 83,5 \\
Toplam & $\mathbf{2 6 0}$ & $\mathbf{1 0 0}$ \\
\hline
\end{tabular}

Şekil 3. Katılımcıların Palladium AVM ile ilgili düşüncelerini ölçmeye yönelik sorulara verdikleri yanıtlar.

Figure 3. Answers of the participants to the questions to measure their thoughts about Palladium Mall.

Katlımcıların önemli bir bölümü (\% 82.4), "Palladium AVM, Antakya'nın en önemli simgelerinden biridir" ifadesine katılmamıştır. Diğer yandan katılımcıların \% 83.5'i, alışveriş merkezinin eski Antakya kent dokusuyla uyumlu olmadığını düşünmektedir (Şekil 3). Böylece konumu itibariyle kabul gören/ beğenilen Palladium AVM'nin mimari yapısı ve tarihi dokusu bakımından Antakya kenti ile uyuşmadığı ifade edilmiştir. Halbuki derinlemesine görüşmelerden elde edilen nitel verilerde, görüşmeye katılanların ifadeleri, bir dönemin üretim mekânı olan Ak-iş iplik fabrikasına olan aidiyetlerini açıkça ortaya koymuştur.

Büyük çoğunluğunu Antakya doğumlu veya yirmi yılı aşkın süredir Antakya'da ikamet edenlerin oluşturduğu katilımcıların \% 60'a yakınının, Palladium AVM'nin yerinde eskiden ne olduğunu bilememeleri, araşttrmanın önemli bulgularındandır. Şüphesiz 18-25 yaş aralığında olanların (\% 32.4), 2007 yılında yıkılan Ak-iş fabrikasını hatırlama olasılıkları oldukça düşüktür. Diğer yandan Antakya doğumlu olmayanlar veya fabrikanın yıkılmasından sonraki süreçte Antakya'da yaşamaya başlayanların da fabrikayı hatırlamaları mümkün olmamıştır. Bununla birlikte, katılımcıların \% 30'a yakın bir kısmı, eskiden Palladium AVM'nin yerinde bir fabrika olduğunu bilmiştir (Şekil 4). Alışveriş merkezinin yerinde boş bir arazi, bahçe, zeytinlik veya tarla olduğunu ifade edenlerin yaşları incelendiğinde, bu kişilerin fabrikanın yıkılması sonrasında bir süre boş kalan araziyi düşünerek cevap vermiş oldukları anlaşılmaktadır. Aynı şekilde eski metruk bir bina olduğunu düşünenlerin belleklerinde fabrikanın bir brownfield (kentsel çöküntü alanı) yapısı olarak yer edinmiş olduğu akıllara gelmektedir. Bugünkü AVM'nin yakın çevresinde yer alan ambar, tabakhane, otogar, köy garajları, hayvan pazarı gibi tesisleri belirten katılımcıların mekân tarifinde algıda tamamlama (bütünleme) ilkesinden etkilenmiş oldukları anlaşılmaktadır.

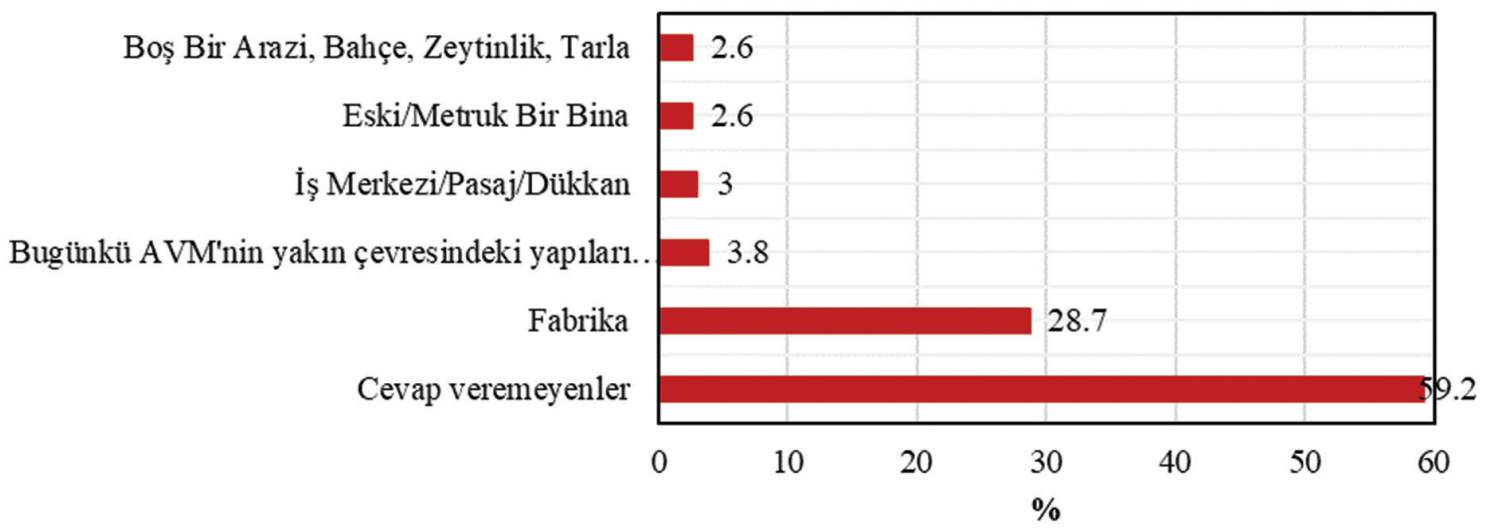

Şekil 4. Katılımcılar tarafindan bugünkü Palladium AVM'nin yerinde eskiden ne vardı sorusuna verilen yanıtlar.

Figure 4. Answers given by the participants to the question of what used to be in place of today's Palladium Mall. 


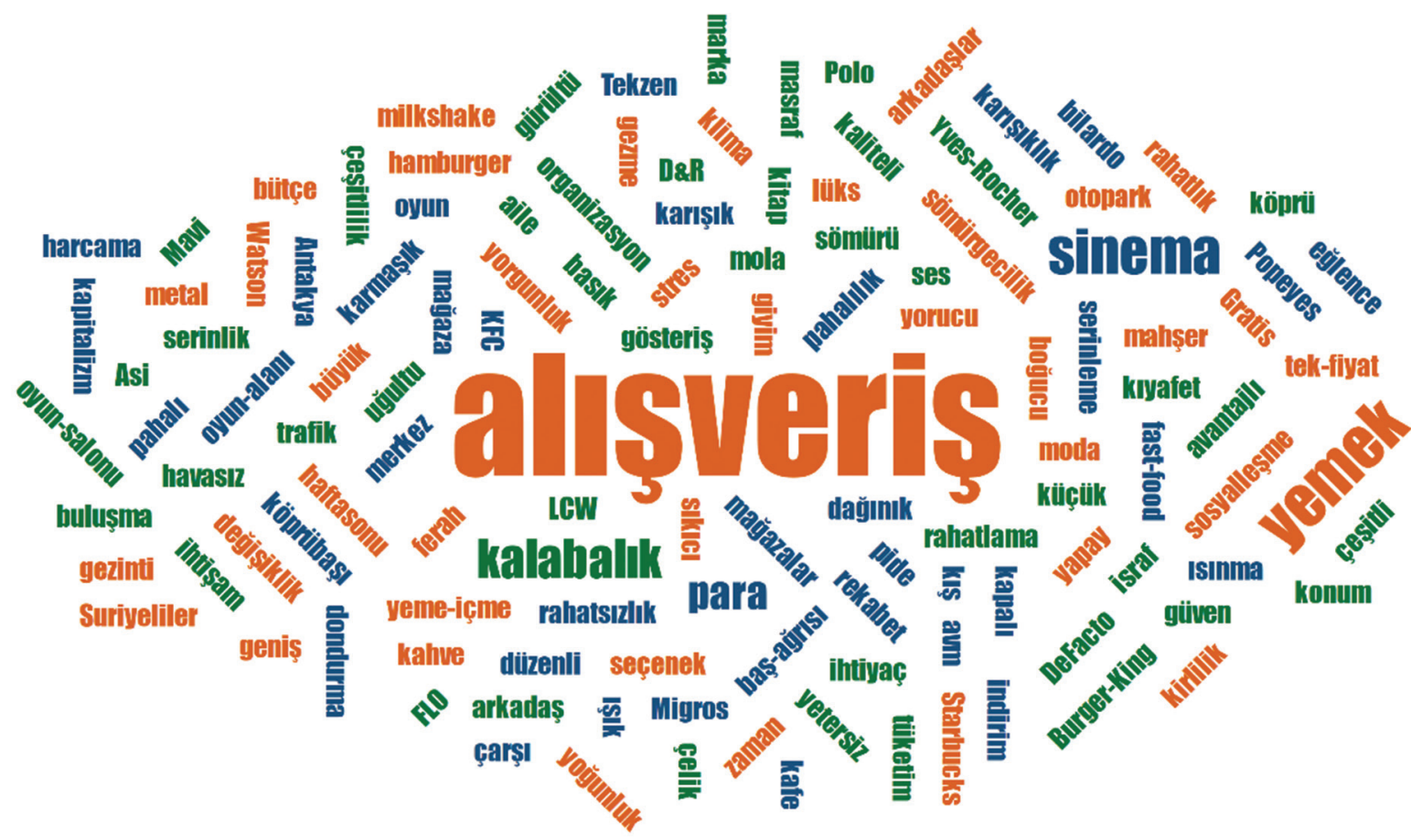

Şekil 5. Katılımcıların Palladium AVM dendiğinde akıllarına gelen ilk üç kelimeye ilişkin kelime bulutu.

Figure 5. Word cloud fort he first three words that come to mind when the participants tihnk of Palladium Mall.

Katılımcıların zihinlerindeki Palladium AVM’ye ilişkin düşüncelerini öğrenme amacıyla sorulan "Palladium AVM dendiğinde aklınıza gelen ilk üç kelime nedir?" sorusuna alınan yanıtlar alışveriş merkezlerinin genel özelliklerine ilişkindir. İlgili soruya katılımcılar tarafindan verilen cevaplarda en sık kullanılan kelime belirgin bir biçimde "alışveriş"tir (99 adet/ \% 16.9). Alışveriş sözcüğünün ardından sırasıyla en sık verilen cevaplar ise; yemek (53 adet/\% 8.9), sinema 47 (\% 7.9), kalabalık (41 adet \% 6.9) ve para (33/\%5.6) gibi daha çok postmodern tüketim kültürüne ilişkin sözcüklerdir. Bununla birlikte görece daha az da olsa kathlımcıların zihinlerinde Palladium AVM'ye iliş̧kin bölgenin yerel yapısıyla ilişkili unsurların da yer edindiği görülmüştür: Asi, köprübaşı, çarşı gibi (Şekil 5).

\section{Tartışma ve Sonuç}

Kentsel mekânın ne şekilde organize edileceği konusu yıllardır süregelen tartışmalardan biri olmuş ve olmaya devam etmektedir. Türkiye'de 1950 'li yıllarda başlayan emek gücüne dayalı kentleşme süreçleri ile 1980'li yıllarda gerçekleşen neoliberal uygulamalar neticesinde ortaya çıkan sermaye ve tüketime dayalı kentleşme süreçleri, kentsel mekânlarda önemli dönüşümleri beraberinde getirmiştir. Söz konusu değişim ve dönüşümlerin Antakya kenti üzerindeki etkilerini ortaya koyma çabası, bu çalışmanın temel motivasyonunu oluşturmuştur.

Bu çalışmanın bulguları, üretim toplumundan tüketim toplumuna geçiş süreçlerinde Antakya kentinin önemli mekânsal dönüşümler geçirdiğini ortaya koymuştur. Derinlemesine görüşmeden elde edilen bilgiler, bir üretim mekânı olarak fabrikanın yeni mekânların (Akevler Mahallesi'nin kurulup gelişmesi, gecekondulaşma gibi) üretilmesinde önemli etkilere sahip olduğunu göstermiştir. Alışveriş merkezinin hizmete girmesiyle birlikte kent merkezinde dikkati çeken en önemli değişimlerden biri cadde mağazacılığından alışveriş merkezi mağaza- cılığına geçiş olmuştur. Bu durum gerek Atatürk Caddesi'nde gerekse alışveriş merkezi çevresindeki ulaşımı doğrudan etkilemiştir. Atatürk Caddesi çift şeritten tek şeride düşürülmüş, diğer yandan postmodern tüketim anlayışına bağlı olarak ulaşım bağlantılarının alışveriş merkezine doğru yönlendirilmesi AVM çevresinde trafik yoğunluğunu arttırmıştır.

Üretim mekânından tüketim mekânına dönüşümün kent üzerindeki ekonomik etkileri incelendiğinde, AVM'nin hizmete girmesinden önce kentin en önemli ve en işlek caddesi durumunda olan Atatürk Caddesinin eski önemini yitirmiş olduğu, bazı işletmelerin tamamen kepenk kapattğı bazılarının ise alışveriş merkezine taşındığı görülmüştür. Ankete katılanların "Alışverişinizi genellikle nereden yaparsınız?" sorusuna verdikleri cevaplar içerisinde Atatürk Caddesi'nin sadece \% 1.9 oranında işaretlenmiş olması caddenin önemini yitirmiş olduğunu açıkça göstermektedir. Bir diğer ekonomik etki, alışveriş merkezi çevresinin arazi değerleri bakımından daha fazla önem kazanması olmuştur. Alışveriş merkezinin hizmete girmesi sonrasında emlak piyasasında yaşanan canlılık ve fiyatların AVM'nin konumuna göre belirlenmesi bu durumu açıkça göstermektedir.

Mekanın dönüşümünün sosyo-psikolojik etkileri incelendiğinde, emek gücüne dayalı kentleşme süreçlerini yaşamış olan kent sakinlerinde fabrikaya yönelik bir aidiyet duygusu geliştiği fabrikanın belleklerinde önemli bir yere sahip olduğu dikkati çekmiştir. Diğer yandan zamanla işlevini yitiren harabe halindeki fabrikanın yıkılması ve yerine alışveriş merkezinin inşa edilmesiyle birlikte köhne, sağlıksız ve güvensiz bir ortamın ortadan kalkmış olduğu anlaşılmıştır. Nitekim anket sorularından birini oluşturan "Palladium AVM çevresinde en önemli sorun nedir?" sorusuna katılımcıların sadece $\% 1,5^{\prime}$ i güvenlik cevabını vermeleri bu durumu destekler niteliktedir. 
Palladium, birçok alışveriş merkezinden farklı olarak Antakya'nın tarihi kent dokusunun bitişiğinde kurulmuştur. Alışveriş merkezinin kentin merkezinde olması ankete katlanlar tarafindan olumlu karşılanmış olmasına rağmen mimari yapısı ve tarihi dokusu bakımından Antakya kenti ile uyuşmadığı belirtilmiştir. Diğer yandan "Palladium alışveriş merkezi denilince aklınıza gelen ilk üç kelime nedir?" sorusuna verilen cevaplar içerisinde en sık tekrarlanan kelimeler; alışveriş, yemek, sinema, kalabalık ve para olmuştur. Şüphesiz bu kelimeler postmodern tüketim kültürüne sahip birçok alışveriş merkezinin karakteristik özelliklerini yansıtmakla birlikte katılımcılar, Palladium Antakya'yı daha fazla ön plana çıkarabilecek Asi, köprübaşı ve çarşı gibi mekânsal unsurları da vurgulamışlardır. Bu durum, Antakya'daki yerel kültürün büyük oranda modernle bütünleşse de hâlâ varlığını sürdürdüğü ve hatta çatışt̆ğını düşündürmektedir. Ne var ki AVM'nin varlığının bu denli kabul edilmesi ise postmodern dönemin biraz da nostaljiden aldığı güçten yahut taktığı nostaljik maskeden kaynaklanmaktadır.

\section{Öneriler:}

Antakya kentinin âdeta bir kimliği ve sembolü durumunda olan ve uzun yıllar köhne (harabe) bir yapı olarak kalan Akİs iplik fabrikasının yıkılması yerine koruma altına alınması ve işlevlendirilmesi suretiyle müze, otel ve hatta alışveriş merkezine dönüştürülmesi söz konusu olabilirdi. Zira Türkiye'de endüstriyel miras yapılarını korumaya yönelik politikalar 1980'li yıllardan itibaren gündeme gelmiş ve İstanbul merkezli olmak üzere birçok kentte endüstriyel miras yapılarının işlevlendirilerek çağdaş kent dokusuna kazandırılmış olduğu görülmüştür Ancak Ak-Iş iplik fabrikasının 1978 yılından 2007 yılına kadar atıl durumda kalmış olması ve daha sonra yıkılması bu konuya yönelik hassasiyetin gösterilmediğini ortaya koymuştur. Hal böyleyken, günümüzde endüstriyel miras niteliği taşıyan yapılara yönelik bir farkındalığın oluşturulması önem arz etmektedir.

Palladium AVM; eğlence mekânları, marka değeri taşıyan işletmeleri, tüketiciye çok fazla seçenek sunması gibi bazı avantajlara sahip olsa da, alışveriş merkezinin Antakya'nın tarihi ticaret merkezinde (MiA) kurulmuş olması her şeyden önce trafik sorunlarını beraberinde getirmektedir. Kent merkezindeki trafik yükünü hafifletebilmek için cadde mağazacılığının geliştirilmesi, çok katlı otoparkların arttrılması ve artk ömrünü tamamlamış olan bazı tesislerin (sebze hali, atölyeler, balıkçılar çarşısı gibi) kentin çevresinde modern standartlarda yeniden inşa edilmeleri gerekmektedir.

Son yıllarda, Atatürk Caddesi üzerinde çeşitli kafe ve restoranların hizmet vermeye başlaması, tarihi meclis binasının turizm amacıyla işlevlendirilmesi, caddenin yeniden çift yönlü trafiğe açılması ve kentsel dönüşüm uygulamaları gibi girişimler caddenin yeniden eski canlıı̆ı̆ına kavuşturulacağı konusunda sinyaller vermektedir. Şüphesiz bu girişimler, içerisinde bulunduğumuz COVID-19 salgını sürecinde açık alanların öneminin daha iyi anlaşılmış olması nedeniyle kıymetlidir.

\section{Etik Kurul İzni}

Hatay Mustafa Kemal Üniversitesi Rektörlüğü Sosyal ve Be- şeri Bilimler Bilimsel Araştırma ve Yayın Etiği Kurulu'nun 03.05.2021 tarih ve 07/12 sayılı kararınca "Modernizmin Üretim Mekânından Postmodernizmin Tüketim Mekânına: Ak-işs İplik Fabrikası - Palladium Antakya AVM Örneği" başlıklı araştırma Yükseköğretim Kurumları Bilimsel Araştırma ve Yayın Etiği Yönergesi kapsamında değerlendirilmiş ve uygun görülmüştür.

\section{Kaynakça}

Agarwal, S., Jensen, J. B., \& Monte, F. (2017). The geography of consumption. Available at SSRN 3002231. https://dx.doi. org/10.2139/ssrn.3002231

Alker, S., Joy, V., Roberts, P., \& Smith, N. (2000). The definition of brownfield. Journal of Environmental Planning and Management, 43(1), 49-69. https://doi.org/10.1080/09640560010766

Arvidson, E. (1999). Remapping Los Angeles or taking the risk of class in postmodern urban theory. Economic Geography, 75(2), 134156. https://doi.org/10.1111/j.1944-8287.1999.tb00120.x

Ayik, U. (2018). Ekonomi politikalarının bir yansıması olarak sanayisizleşme ve mekânsal değişim: istanbul örneği (Yayın no: 533245), [Doktora Tezi, İstanbul Üniversitesi] Yükseköğretim Kurulu Başkanlığı Tez Merkezi.

Ayşın, F., \& Turhanoğlu, K. (2014). Kentsel mekânın üretim sürecinde tarihi ve kültürel miras. Uluslararası Kıbrıs Üniversitesi Folklor/ Edebiyat Dergisi, 20(78), 71-82.

Azizağaoğlu, A., \& Altunışık, R. (2012). Postmodernizm, sembolik tüketim ve marka. Tüketim ve Tüketim Araştrrmaları Dergisi, 2(4), 33-50.

Bat, U. (2007). Kentin postmodernitesi: postmodern tüketim kültürü ışığında hedonik bir biçim olarak kent tasarımı. Journal of Istanbul Kültür Universty, 4(5).

Batu, M., \& Tos, O. (2017). Tüketim kültürü odağında modernizm ve postmodernizmin karşılaştrılması. Gümüşhane Üniversitesi Iletişim Fakültesi Elektronik Dergisi, 2(5), 991-1023. https://doi. org/10.19145/e-gifder.296888

Bayazıt-Hayta, A. (2014). Postmodern dönemin tüketim imajları: postmodern tüketim kültürü, tüketim kalıpları ve postmodern tüketici. İçinde Babaoğul, M., Şener, A., Buğday, E.B. (Ed.) Tüketici Yazıları IV Kitabı. (ss.9-32). Eryılmaz Offset Matbaacılık.

Bayhan, H. (2006). Ulus devlet, modernizm ve postmodernizm (Yayın no: 204336) [Yüksek Lisans Tezi, Dicle Üniversitesi] Yükseköğretim Kurulu Başkanlığı Tez Merkezi.

Belge, R. (2018). Denizli kent kimliğini oluşturan coğrafi öğeler. Ege Coğrafya Dergisi, 27(2), 167-181.

Berman, M. (1988). All that is solid melts into air: the experience of modernity. Penguin Books.

Çalışkan, V. (2002). Amik Ovası'nın beşeri ve iktisadi coğrafyası (Yayın no: 135262) [Doktora Tezi, İstanbul Üniversitesi] Yükseköğretim Kurulu Başkanlığı Tez Merkezi.

Çeker, A., \& Belge, R. (2015). İstanbul'da kentsel dönüşüm kapsamında gerçekleşen bir olgu: Soylulaştirma. Türk Coğrafya Dergisi, 65, 77-86. https://doi.org/10.17211/tcd.30494 
Çetin, B. (2012). Hatay'da kentleşmenin seyri (1940-2009) ve mekânsal dağılışı. Doğu Coğrafya Dergisi, 17(28), 231-257.

Dear, M. (1986). Postmodernism and planning. Environment and Planning, Society and Space, (4), 367-384. https://doi. org/10.1068/d040367

Dear, M. (2000). The postmodern urban condition. Blackwell Publishing.

Dear, M., \& Flusty, S. (1998). Postmodern urbanism. Annals of Association of American Geographers, 1(8), 50-72. https://www. jstor.org/stable/2563976.

Dinç, Y. \& Üçeçam Karagel, D. (2020). Antakya şehrinin kuruluşu ve mekânsal gelişimi. İçinde Arslan, F. (Ed), Türkiye Coğrafyası Araştrrmaları Kitabı (ss. 571-596). Pegem Akademi.

Doğanay, H., \& Çavuş, A. (2011). Türkiye ekonomik coğrafyası (7.Baskı). Pegem Akademi Yayıncılık.

Ellin, N. (1999). Postmodern urbanism. Princeton Architectural Press.

Emekli, G. (2018). Kent turizminde kültür ve yaratıcılık İçinde TÜCAUM 30. Yıl Uluslararası Coğrafya Sempozyumu 3-6 Ekim 2018 Bildiriler Kitabı, (ss. 469-489).

Er, K. (2014). Üretim ilişkileri temelinde modernizm ve postmodernizmin az gelişmiş ülkeler üzerine etkileri. Dokuz Eylül Üniversitesi Sosyal Bilimler Enstitüsü Dergisi, 16(3), 413-453. https://doi. org/10.16953/deusbed.39137

Eraydın, A. (1988). Sermaye birikim sürecinde kentler. Defter Dergisi, (5), 133-153.

Eraydın, A. (1992). Post-fordizm ve değişen mekânsal öncelikler ODTÜ Mimarlık Fakültesi Matbaası.

Erdoğan, Ö. (2013). Ankara kentindeki alışveriş merkezlerinin yer seçim tercihleri ve mekânsal etkileri (Yayın no: 348204) [Yüksek Lisans Tezi, Ankara Üniversitesi] Yükseköğretim Kurulu Başkanlığı Tez Merkezi.

Erkip, F. (2003). The shopping malls as an emergent public space in Turkey. Environment and Planning, (35), 1073-1093. https://doi. org/10.1068/a35167

Goss, J. (2004). Geography of consumption. I. Progress in Human Geography, 28(3), 369-380. https://doi.org/10.1191/0309132504p$\underline{\mathrm{h} 486 \mathrm{pr}}$

Goss, J. (2006). Geographies of comsumption: the work of consumption. Progress in Human Geography, 30(2), 237-249. https://doi. org/10.1191/0309132506ph604pr

Gottdiener, M. (2005). Postmodern göstergeler. (Çev. Erdal Cengiz, Hakan Gür, Arhan Nur). İmge Kitapevi.

Gürsel, D. (2015). Modern ve postmodern dönem mekânsal yaklaşımların değerlendirilmesi: Şandigar, Poundbury ve Orestad örneği, (Yayın No: 381858) [Yüksek Lisans Tezi, İstanbul Teknik Üniversitesi] Yükseköğretim Kurulu Başkanlığı Tez Merkezi.

Harvey, D. (1990). Flexible accumulation through urbanization reflections on "post-modernism" in the American City. Perspecta, Theater, Theatrically and Architecture, (26), 251-272. https:// doi.org/10.2307/1567167

Harvey, D. (2010). Postmodernliğin durumu, (Çev. Sungur Savran). Metis Yayıncılık.

Harvey, D. (2015). Sermayenin mekânları (2. Baskı) Sel Yayıncılık.

Hatipler, M. (2017). Postmodernizm, tüketim, popüler kültür ve medya. Bilgi, (1), 32-50.
Işık, Ş. (2005). Türkiye'de kentleşme ve kentleşme modelleri. Ege Coğrafya Dergisi, 14(1-2), 57-71.

Kando, T. (1996). Postmodernism: old wine in new bottles? International Journal of World Peace, 13(3), 3-33.

Karadağ, A., \& Incedere, L. (2017). Türkiye'de endüstriyel mirasın korunması. İçinde Arslan, F. (Ed), Türkiye Coğrafyası Araştırmaları Kitabı (ss. 13-42). Pegem Akademi.

Karadağ, A., \& İncedere, L. (2020). Kentsel belleğin sürdürülebilirliği açısından İzmir'deki endüstri miras alanlarının önemi: Alsancak Limanardı Bölgesi örneği. Ege Coğrafya Dergisi, 29(1), 57-71.

Kaygalak, I., \& Işık, Ş. (2007). Kentleşmenin yeni ekonomik boyutları. Ege Coğrafya Dergisi, 16(1-2), 57-77.

Kaypak, Ş. (2013). Modernizmden postmodernizme değişen kentleşme. Küresel iktisat ve İşletme Çalışmaları Dergisi, 2(4), 80-95.

Keleş, R. (2015). Kentleşme politikası. İmge Kitapevi.

Kongar, E. (2003). Toplumsal değişme kuramları ve Türkiye gerçeği. Remzi Kitabevi.

Korkusuz, T. (2020). Erzurum kentinde alışveriş ve fuar turizmi, Fenomen Yayınevi.

Kırılmaz, H., \& Ayparçası, F. (2016). Modernizm ve postmodernizm süreçlerinin tüketim kültürüne yansımaları. Insan \& Insan Dergisi, 8(3), 32-58.

Laçiner, Ö. (1996). Kentlerin dönüşümü. Mimarlık Dergisi, (271), 3641.

Lefebvre, H. (1976). Survival of capitalism. Macmillan.

Lefebvre, H. (2003). The urban revolution. University of Minnesota Press.

Lefebvre, H. (2015). Mekânın üretimi, (Çev. Işık Ergüden). Sel Yayıncllık.

Leoen, B.B. (2017). Urban theory in postmodern cities: amnesiac spaces and ephemeral aesthetics. URBS, Revista de Estudios Urbanos y Ciencias Sociales, 1(7), 57-65.

Logemann, J. (2009). Where to shop? The geography of consumption in the twentieth-century Atlantic world. Bulletin of the German Historical Institute, (45), 55-68.

Mansvelt, J. (2010). Geographies of consumption: engaging with absent presences. Progress in Human Geography, 34(2), 224-233. https://doi.org/10.1177/0309132509339934

Öztürk, M. (2015). Coğrafya öğretmenlerinin postmodern coğrafya algıları. Eğitim ve Bilim Dergisi, 37(166), 262-274.

Sarı, B. (2019). Modernizmden postmodernizme tüketimin evrimi ve ekonomi politiğini anlamak. Elektronik Sosyal Bilimler Dergisi, 70(18), 554-568.

Scraton, S., \& Watson, B. (1998). Gendered cities: women and public leisure space in the postmodern city, Leisure Studies, 2(17), 123137. https://doi.org/10.1080/026143698375196

Soja, E. (2015). Postmodern coğrafyalar, (Çev. Yunus Çetin). Sel Yayıncilık.

Şan, M.K., Hira, i., \& Saraçoğlu, A.D. (2017). Kentlerin yeni tüketim mabetleri: alışveriş merkezleri. Sosyal ve Kültürel Araştırmalar Dergisi, 5(3), 149-169.

Şengül, T. (2009). Kentsel çelişki ve siyaset. İmge Kitapevi. 
Timor, A.N. (2001). Pazarlama coğrafyası açısından büyük alışveriş merkezleri ve İstanbul örneği. Coğrafya Dergisi, (9), 53-80.

Turut, H., \& Özgür, E.M. (2018). Klasik kent kuramlarından eleştirel kent kuramlarına geçiş bağlamında kentleri yeniden okumak. Ege Coğrafya Dergisi, 27(1), 1-19.

Tut, G. (2013). Neoliberal ekonomide turizm ve rant: Kuşadası kruvaziyer limanı özelleştirilmesi örneği, (Yayın no: 342241) [Yüksek Lisans Tezi, Trakya Üniversitesi] Yükseköğretim Kurulu Başkanlığı Tez Merkezi.

Tümertekin, E. (1973). Türkiye'de şehirleşme ve şehirsel fonksiyonlar. İstanbul Üniversitesi Coğrafya Enstitüsü Yayınları.

Türk Dil Kurumu Sözlüğü (2021). "Modernizm”. https://sozluk.gov. tr/, Erișim Tarihi:18.05.2021.

Uğur, A., \& Aliağaoğlu A. (2018). Şehir coğrafyası (6.Basım). Nobel Yayınevi.

Verdil, F.T. (2006). Alışveriş mekânlarının oluşumu/kurgusu üzerine bir değerlendirme (Yayın no: 172171) [Yüksek Lisans Tezi, İstanbul Teknik Üniversitesi] Yükseköğretim Kurulu Başkanlığı Tez Merkezi.

Vural-Arslan, T. (2009). Türkiye'deki alışveriş merkezleri incelemelerine eleştirel bir bakış: yorumlar, eleştiriler, tartışmalar. Uludağ Üniversitesi Mühendislik-Mimarlık Fakültesi Dergisi, 14(1), 147159 